\title{
The real effects of capital controls: Firm-level evidence from a policy experiment
}

\author{
Laura Alfaro $^{\mathrm{a}, *}$, Anusha Chari ${ }^{\mathrm{b}}$, Fabio Kanczuk ${ }^{\mathrm{c}}$ \\ a Harvard Business School, Morgan 267, Boston, MA 02163, United States \\ b Department of Economics, CB \#3305, University of North Carolina at Chapel Hill, Chapel Hill, NC 27599, United States \\ c Deparment of Economics, University of São Paulo, Av. Prof. Luciano Gualberto, 908, Cidade Universitária Armando Salles de Oliveira Butantã, São Paulo 05508-010, Brazil
}

\section{A R T I C L E I N F O}

Article history:

Received 31 May 2016

Received in revised form 24 April 2017

Accepted 15 June 2017

Available online 23 June 2017

JEL classification:
F3
F4
G1
H22
L2
Keywords:
Capital controls
Discriminatory taxation
International investment barriers
Cost of capital
Exports

\section{Introduction}

The massive surge of foreign capital to emerging markets in the aftermath of the global financial crisis of 2008-2009 has led to a renewed debate about the merits of the free flow of international capital. Given the very low interest rates in developed economies, investors were attracted to the higher rates in Brazil, Chile, Taiwan, Thailand, South Korea, and many other emerging markets (Fratzscher, 2012). To stem the flow of capital and manage the attendant risks several emerging markets imposed taxes or controls to curb inflows of

is We thank George Alessandria, Alessandra Bonfiglioli, Robin Greenwood, Sebnem Kalemli-Ozcan, Nicolas Magud, Elias Papaioannou, James Kalori, Seppo Pynnonen, Adi Sunderam, participants at the NBER-CBRT pre-conference and conference on Monetary Policy and Financial Stability, the Barcelona GSE-Summer Forum-International Capital Flows Conference, the Exchange Rates and External Adjustment Conference in Zurich, LACEA, the Indian Ministry of Finance's NIPFP-DEA conference, AEA Meetings-San Francisco and seminar participants at the IMF, UNC-Chapel Hill, University of Sao PauloFEA, Harvard-DRCLAS for helpful comments and suggestions. We also thank Hayley Pallan, Elizabeth Meyer and Hilary White for excellent research assistance and HBS for financial support.

* Corresponding author.

E-mail addresses: lalfaro@hbs.edu (L. Alfaro), achari@unc.edu (A. Chari), kanczuk@ups.br (F. Kanczuk). foreign capital. ${ }^{1}$ Further, in December of 2012, the International Monetary Fund (IMF) released an official statement endorsing a limited use of capital controls (IMF, 2012).

The case for capital controls primarily rests on macro-prudential measures designed to mitigate systemic risk as well as the volatility of foreign capital inflows. However, controls can also have an implicitly protectionist or mercantilist motive to maintain persistent currency undervaluation (Pasricha, 2017; Jeanne et al., 2012; Magud et al., 2011; Magud and Reinhart, 2007). Policy makers from emerging Asia and Latin America expressed concerns that massive foreign capital inflows can lead to an appreciation of the exchange rate and loss of competitiveness, with potentially lasting effects on the export sector.

Our paper is the first to provide direct empirical evidence of the costs of controls on foreign capital inflows using firm-level data from Brazil seen as a poster child for the recent policy changes. Previous research

\footnotetext{
1 According to the governor of Taiwan's central bank, Perng Fai-Nan "The US printed a lot of money, so there's a lot of hot money flowing around. We see hot money in Taiwan and elsewhere in Asia.... These short-term capital flows are disturbing emerging economies." Similarly, Reserve Bank of India (RBI) Governor Raghuram Rajan warned of the risk of a global market "crash" should foreign investors start bailing out of their risky asset positions in emerging markets generated by the loose monetary policies of developed economies.
} 
shows that a variety of barriers can segment international capital markets (Stulz, 2005; Henry, 2007). Legal constraints, institutional quality, foreign ownership restrictions, discriminatory taxes, and transaction costs such as information asymmetries affect international portfolio choice. The type of international investment barrier we study in this paper is the effect of discriminatory taxation of foreign investors. The Brazilian Imposto Sobre Operações Financeiras (IOF) constitutes such a discriminatory tax as it contributes explicitly to the direct costs of foreigners investing in Brazilian financial markets.

Focusing on Brazil has several advantages. First, Brazil applied a series of capital controls measures that ranged across debt, equity and derivative instruments between 2008 and 2013. We have detailed information about the policy changes as they relate to specific instruments and magnitudes. Second, we have a precise set of announcement dates that facilitate a clean identification strategy to quantify the market's reaction to the capital control announcements. Third, stock market data and comprehensive firm-level financial statement data provide us with a rich and unique setting to examine the impact of these policy changes on Brazilian firms.

The data offer valuable cross-sectional variation to test for (a) cost of capital and exchange rate effects, and (b) the impact of external finance dependence and credit constraints in the aftermath of the controls. Importantly, firm-level data have the advantage that they can shed light on the channels through which capital controls affect Brazilian firms. Fourth, we have access to proprietary export data from the Brazilian export authority (Secex) for the listed Brazilian firms. The firm-level export data allow us to examine both the firm-level response to capital flows as well as the impact of capital controls on the competitiveness of exporting firms.

Theoretically, when a country imposes capital controls taxes, expected returns on the risky assets subject to the tax would increase. Capital controls impose investment barriers that segment international capital markets, creating a price wedge that drives up the expected return relative to the benchmark return under full integration (Stulz, 1981). Further, capital controls can affect the cost of external finance and therefore firms that rely on external finance to fund their investment opportunities (Rajan and Zingales, 1998). Using firm-level data, we also test whether external finance dependent firms (or industries) in Brazil are more adversely affected by capital controls. In particular, we conduct an event-study analysis using capital control announcement dates together with stock prices and firm-level data from Datastream, Worldscope, and Secex.

The key results are as follows. First, consistent with an increase in expected returns or the cost of capital, on average, there is a significant decline in cumulative abnormal returns for Brazilian firms following the imposition of capital controls on foreign portfolio inflows in 2008-2009. Evidence about the mechanism by which the cost of capital rises suggests that on average market interest rates increase significantly in the aftermath of the controls. It is worth noting that these interest rates increase against the backdrop of quantitative easing in the US and other developed countries that put downward pressure on the world interest rate. We also use imputed cost of capital measures to provide corroborating evidence that the cost of capital goes up significantly following capital control announcements.

Second, the data suggest that large firms are less affected by the controls, perhaps consistent with large-firm access to internal capital markets or alternative sources of finance. Third, we find that exporting firms are less adversely affected by controls. The coefficient estimates suggest that the larger exporting firms, in particular, are somewhat shielded. Fourth, we find that external-finance dependent firms that are more dependent are more adversely affected by the capital controls.

Fifth, controls on debt flows are associated with less negative returns, suggesting that the market views equity and debt flows as different. Historically, Brazil experimented with the IOF tax exclusively on debt flows, extending the purview to include equity instruments was done for the very first time in October 2009 (see Goldfajn and Minella,
2007). The market's reaction may, therefore, be capturing the element of surprise or unexpected nature of the policy change to include equity flows.

Earlier studies primarily focused on foreign ownership restrictions where either a subset of domestic assets or certain share classes are made available to foreign investors (Chari and Henry, 2004, 2008; Henry, 2007). In contrast, our paper provides systematic evidence on the impact of discriminatory taxation of foreign investors via the IOF on the stock market valuation of Brazilian firms. A related paper, Forbes et al. (forthcoming), shows that an increase in Brazil's tax on foreign investment in bonds causes investors to significantly decrease their portfolio allocations to Brazil in both bonds and equities. Investors simultaneously decrease allocations to countries viewed as more likely to use capital controls. Similarly, Forbes (2007a) studies the impact of Chilean Encaje experiment with unremunerated reserve requirements in the 1990s on the financial constraints that small, traded firms face (see also Forbes, 2007b).

More generally, a growing theoretical macro literature posits the benefits of capital controls albeit focusing exclusively on debt rather than equity to motivate the model frameworks (Bianchi and Mendoza, 2013; Farhi and Werning, forthcoming; Korinek, 2010). On the empirical front, Klein (2012) casts doubts about assumptions behind recent calls for a greater use of episodic controls on capital inflows and finds, with a few exceptions, there is little evidence of the efficacy of capital controls.

Similarly, contrary to prescriptions put forth in the recent theoretical macro literature, Fernández et al. (2013) do not find evidence of capital controls implemented as macro-prudential tools in the period 20052011. In a related paper, Glick et al. (2006) find that countries with liberalized capital accounts experience a lower likelihood of currency crises. Obstfeld et al. (2005) find that historical data bear out the constraints implied by the trilemma between exchange rate stability, monetary policy autonomy and capital mobility.

The paper proceeds as follows. Section 2 reviews the macroeconomic conditions in Brazil in the 2000s and provides information about the recent use of capital controls measures. Section 3 provides a brief theoretical motivation and details about the event study methodology. Section 4 describes the data and summary statistics. Section 5 presents the results and additional tests to ensure the robustness of our findings. Section 6 concludes.

\section{Background: Brazil in the 2000s and the recent use of capital control taxes}

Except for a brief recession during the last two-quarters of 2008 , caused by the global financial crisis, the Brazilian economy expanded throughout the 2000s due to a commodity exports and consumer boom. The impact of the financial crisis was short lived, and Brazil's economy swiftly returned to growth by the second quarter of 2009. The commodity boom, paired with increased inflows of foreign capital, placed upward pressure on the Brazilian currency, the Real..$^{2}$ In 2008, the Real appreciated by $50 \%$ to $1.6 \mathrm{R} \$ / \mathrm{US} \$$ from a low of $3.1 \mathrm{R} \$ / \mathrm{US} \$$ in $2004^{3}$

In an attempt to prevent an excessive inflow of foreign capital, stabilize the exchange rate, and reduce the upward trend in inflation, Brazil's government adopted a system of capital controls on inflows from abroad. In March 2008, the government established the Imposto Sobre Operações Financeiras (IOF), a financial transaction tax of $1.5 \%$ placed on incoming foreign fixed-income investments effectively immediately, as a means of quelling the flow of capital into the economy.

\footnotetext{
2 The International Institute of Finance estimated that foreign capital inflows increased from US\$11.2bn in 2006 to US\$79.5bn in the following year. Brazil emerged as the biggest recipient of foreign capital in Latin America and the second highest among emerging markets after China.

${ }^{3}$ Banco Central Do Brasil accessed November 29, 2012.
} 
Note that the IOF is a tax that can be levied on a range of financial operations including foreign credit, foreign exchange, securities, and so on. Also, it is a tax over which the executive branch has very broad powers regarding triggering events and applicable rates. ${ }^{4}$ Under the Brazilian Constitution, the National Congress by law has to approve most tax increases and changes usually take effect after ninety days. However, the IOF is an exception-a "policy decree" can modify the tax that ranks below a law and does not require Congressional ratification. On a discretionary basis, the Finance Ministry can overnight change the IOF tax that becomes effective immediately from its enactment date. Using data from investor interviews, Forbes et al. (forthcoming) document that investors did not anticipate the controls. Appendix A provides specific details about the IOF tax legislation.

By October of 2008, the wide-reaching effects of the international financial crisis were becoming clear. Net foreign capital inflows dropped from US\$88.3 billion in 2007 to US\$28.3 billion in 2008. In particular, net foreign portfolio investments of debt and equity fell from US $\$ 48.1$ billion in 2007 to - US $\$ 0.77$ billion in 2008 . To stem the outflow of investment the government eliminated the IOF.

However, Brazil recovered quickly from the economic downturn, and during the first nine months of 2009, approximately US\$20 billion of primarily US-led foreign investments entered the Brazilian equities market. ${ }^{5}$ With the resumption of massive capital inflows, capital controls were imposed again as early as February of 2009. On October 20,2009 , Brazilian authorities expanded the IOF tax to a $2 \%$ rate on fixed income, in addition to portfolio and equity investments. The IOF did not apply to inflows of direct investment.

Since its re-introduction in October of 2009, the IOF tax was repeatedly raised and expanded to include other forms of investments by the Brazilian government to control the influx of foreign capital (see Table 1 for a detailed list). By late 2010, the Real continued to appreciate, emerging as one of the strongest performing currencies in the world. On October 5, 2010, the IOF on fixed-income instruments was raised to $4 \%$; less than two weeks later the tax was raised to $6 \%$.

In early 2011, the exchange rate remained at R\$1.6 against the U.S. dollar, and the blame for Brazil's currency appreciation was targeted on incoming foreign capital originating in developed markets with US flows accounting for the largest fraction of these flows. The government decided to raise the IOF to $6 \%$ on foreign loans with a minimum maturity of up to 360 days in March 2011. By early April, the IOF was extended to loans with a maturity of up to two years. The increase in tax rate represented a shift away from a dependency on high interest rates to combat the growing levels of inflation in Brazil. In an attempt to depreciate the value of the Real, the Central Bank also aggressively cut its overnight rate (Selic). Over a ten-month period, the Selic rate was cut eight consecutive times, from $12.5 \%$ in late August 2011 to $8 \%$ in July $2012 .{ }^{6}$

In early December 2011, however, the $2 \%$ IOF tax on equities was removed. In the first week of June 2013, Brazil removed the tax on foreign investments in local debt and the $1 \%$ tax charged currency derivatives. ${ }^{7,8}$ On July 1 st, the government further eliminated reserve requirements on short dollar positions held by local banks. ${ }^{9}$

Details about the implementation procedure for the IOF tax (Appendix A) suggest that the capital controls announcements

\footnotetext{
4 See www.receita.fazenda.gov.br/aliquotas/impcresegcamb.htm.

5 "Brazil Increases Tax on Foreign Exchange Transactions Related to Foreign Investments in the Financial and Capital Markets," Memorandum, Simpson Thatcher \& Bartle LLP, October 22, 2009.

${ }^{6}$ Chamon and Garcia (2016) show that the while controls were effective in partially segmenting the Brazilian financial market from the international markets, they do not seem to have deterred the appreciation of the real when capital inflows were strong.

7 http://www.bloomberg.com/news/2013-06-13/brazil-dismantles-capital-control-asreal-drops-to-four-year-low.html.

8 http://www.reuters.com/article/2013/06/05/brazil-tax-iof-idUSL1NOEG23E20130605.

9 http://www.bloomberg.com/news/2013-06-25/brazil-eliminates-reserve-requirementon-bets-against-the-dollar.html.
}

surprised most market participants. A candidate explanation for the element of surprise is also that the set of instruments that were included under the umbrella of capital controls was extended to equity and other instruments previously not been subject to them. Previous experiments were restricted to debt instruments. Now the purview was broadened to include equity, ADRs, derivative contracts and other instruments. Moreover, the rates were changed in an ad hoc fashion. It is possible that after the first controls had been announced in March 2008, the market might have anticipated that the economy was in a new capital controls regime. However, these controls were quickly removed in light of the Lehman collapse and the global financial crisis. ${ }^{10}$ Subsequently the controls were reintroduced in October 2009 and implemented with a widening reach in the two and a half years that followed.

It is nevertheless important to acknowledge that any policy change that results in winners and losers would be subject to media attention as various constituents in a democracy express their views about an impending change or trend in policy direction. If capital controls were expected to drive up the cost of capital, external finance dependent firms and smaller firms would stand to lose and be opposed to the controls. Similarly, if there was an unprecedented move to implement controls on equity flows, firms listed on the stock market or stock exchange executives may voice their opposition to the controls. For example, the decision to place capital controls on incoming foreign investments was not unanimously supported. Edemir Pinto, chief executive of the Brazilian Stock Exchange, called on the government to remove some of the existing capital controls because the IOF was damaging the stock market. Over half of the capital raised by Brazilian companies from IPOs originated from foreign investors, and Pinto claimed the tax on financial transactions was choking foreign inflows of capital. ${ }^{11}$

On the other hand, as a result of the massive capital inflows the constituent firms most likely to be hurt by a Real appreciation are exporters whose competitiveness would be adversely affected in world markets. Exporting firms would, therefore, stand to gain if the implementation of capital controls led to a reversal of the Real appreciation. Also note that the IOF tax rate is zero on foreign exchange transactions related to the inflow of revenue derived from the export of goods and services and outflow of funds derived from the import of goods. To assess whether different constituents expressed opinions in the media, we undertook a detailed survey of Brazilian newspapers, business journals, and other press sources. Appendix B presents a sample of these articles. Please note that most of these articles are in Portuguese.

The next section briefly discusses the theoretical underpinnings and the empirical methodology.

\section{Theoretical underpinnings and the event study methodology}

In addition to offering domestic investors an expanded opportunity set for portfolio diversification purposes, international investment entails two unique dimensions that are not particularly relevant in the context of purely domestic investments namely exchange rate risk and the problem of market segmentation. With respect to market segmentation, international asset pricing models incorporate capital flow restrictions (for instance, Black, 1974; Stulz, 1981; Lessard, 1983) and analyze the pricing effects of investment barriers.

\footnotetext{
10 On October 22nd 2008, the IOF tax was removed but this coincides with a massive decline in the US stock market in the midst of the global financial crisis-the S\&P 500 index fell by $6.1 \%$ and the Dow Jones Industrial Average recorded a loss of 514 points, or $5.7 \%$. Given that we do not want this date to confound the results, we exclude this event date from our estimations. Note that the results remain robust to the inclusion of this event (not reported but available upon request).

11 Robert Cookson and Joe Leahy, "Call to ease Brazil's capital controls" Financial Times, October 25, 2011.
} 
Table 1

Capital Controls in Brazil: 2008-2013.

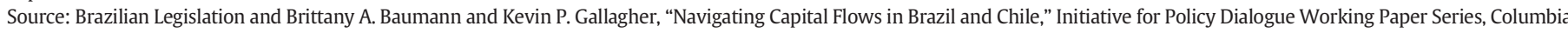

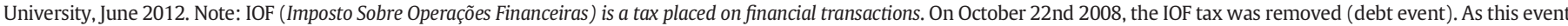

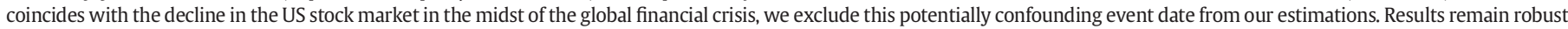
to the exclusion/inclusion of this event.

\begin{tabular}{|c|c|c|c|c|c|c|c|}
\hline $\begin{array}{l}\text { Announcement } \\
\text { date }\end{array}$ & $\begin{array}{l}\text { \% change } \\
\text { Bovespa } \\
\text { (1-day after) }\end{array}$ & Event type & Event & $\begin{array}{l}\text { Debt } \\
\text { event }\end{array}$ & $\begin{array}{l}\text { Equity } \\
\text { event }\end{array}$ & $\begin{array}{l}\text { Effective } \\
\text { date }\end{array}$ & $\begin{array}{l}\text { Decree } \\
\text { number }\end{array}$ \\
\hline $3-12-2008$ & $0.17 \%$ & Tightening & IOF tax $=1.5 \%$ on fixed income investments made by non-residents & 1 & 0 & $3-17-2008$ & 6391 \\
\hline 10-19-2009 & $-2.88 \%$ & Tightening & $\mathrm{IOF} \operatorname{tax}=2 \%$ introduced on equities and fixed income securities & 1 & 1 & $10-20-2009$ & 6983 \\
\hline 11-18-2009 & $-0.28 \%$ & Tightening & Tax $=1.5 \%$ on American Depositary Receipts (ADRs) converted into local stocks & 0 & 1 & 11-19-2009 & 7011 \\
\hline $10-4-2010$ & $1.28 \%$ & Tightening & IOF tax $=4 \%$ on fixed income bonds and derivatives; $2 \%$ for equities & 1 & 0 & $10-5-2010$ & 7323 \\
\hline $10-18-2010$ & $-2.61 \%$ & Tightening & IOF tax $=6 \%$ on fixed income bonds and derivatives; $2 \%$ for equities & 1 & 0 & $10-19-2010$ & 7330 \\
\hline $12-30-2010$ & $0.00 \%$ & Tightening & IOF tax $=2 \%$ on American Depositary Receipts, converted into local stocks & 0 & 1 & $12-31-2010$ & 7412 \\
\hline $3-28-2011$ & $0.34 \%$ & Tightening & IOF tax $=6 \%$ on overseas loans and bonds with maturities up to 1 year & 1 & 0 & $3-29-2011$ & 7456 \\
\hline $4-6-2011$ & $0.20 \%$ & Tightening & IOF tax to overseas bonds with maturities up to 2 years & 1 & 0 & $4-7-2001$ & 7457 \\
\hline 7-26-2011 & $-1.77 \%$ & Tightening & Tax of $1 \%$ on foreign exchange derivatives; legislation allow tax to be increased up to $25 \%$ & 0 & 1 & $7-27-2011$ & 7536 \\
\hline $12-1-2011$ & $-0.44 \%$ & Easing & IOF tax $=0 \%$ on variable income instrum. traded on the exchange and certain debentures & 0 & 1 & $12-2-2011$ & 7632 \\
\hline $2-29-2012$ & $1.52 \%$ & Tightening & IOF tax to cover overseas loans and bonds with maturities up to 3 years & 1 & 0 & $3-1-2012$ & 7683 \\
\hline $3-9-2012$ & $-0.48 \%$ & Tightening & IOF tax to cover overseas loans and bonds with maturities up to 5 years & 1 & 0 & 3-12-2012 & 7698 \\
\hline $5-21-2012$ & $-2.74 \%$ & Easing & $\mathrm{IOF} \operatorname{tax}=1.5 \%$ for individual borrowers (from $2.5 \%$ ) & 1 & 0 & $5-22-2012$ & 7726 \\
\hline 6-13-2012 & $-0.54 \%$ & Easing & IOF tax to overseas loans and bonds with maturities up to 2 years & 1 & 0 & $6-14-2012$ & 7751 \\
\hline $12-4-2012$ & $0.20 \%$ & Easing & IOF tax to overseas loans and bonds with maturities up to 1 year & 1 & 0 & $12-5-2012$ & 7853 \\
\hline $12-23-2013$ & $-1.46 \%$ & Easing & IOF tax $=0 \%$ on American Depositary Receipts, converted into local stocks & 0 & 1 & $12-24-2013$ & 8165 \\
\hline
\end{tabular}

Barriers to international investment may take many forms such as exchange and capital controls by governments, which restrict the access of foreigners to the local capital markets, reduce their freedom to repatriate capital and dividends, and limit the fraction of a local firm's equity that foreigners may own (Chari and Henry, 2004). Foreign investors may face a lack of information, expropriation fears, or more importantly subject to discriminatory taxation. It follows that the existence of such barriers will constrain portfolio choice by affecting the de facto international investment opportunity set facing investors. Therefore, the resulting optimal international portfolio allocation could well be very different from that under perfect integration. In other words, barriers such as discriminatory taxation of foreign investments can segment international financial markets by constraining portfolio choice.

Given the variety of barriers to international investment, the challenge for researchers is, therefore, to isolate and quantify important barriers and then investigate their impact on portfolio behavior and on asset pricing relationships (Solnik, 1974). For instance, Black (1974) and Stulz (1981) construct models of international asset pricing where it is costly for domestic investors to hold foreign securities due to discriminatory taxation. Theoretically, these models come closest to the Brazilian IOF taxes imposed on foreign investors. Note that in the two models the barrier may represent a transaction cost, information cost, or differential taxation. Both models assume that proportional taxation can represent this cost and use a two-country, single-period model for analysis. In the Black model, the tax is on an investor's net holdings (long minus short) of risky foreign assets. Stulz (1981) models taxes on the absolute value of an investor's long and short holdings of risky foreign assets. Both models show that the world market portfolio will not be efficient for any investor in either country. Stulz also shows that under some conditions the domestic investor's portfolio may altogether preclude a subset of foreign securities.

Appendix C presents a modified outline of the model in Stulz (1981) to help fix ideas. To motivate our empirical analysis in simple terms we can think of the controls as creating a price wedge in the expected returns or a tax that drives up the expected return relative to the benchmark return under full integration. An increase in expected returns will result in falling stock prices. In mapping the theory to the data, in an event study framework, an increase in expected returns and a fall in stock prices will be reflected in negative cumulative abnormal returns (CARs) in the event windows surrounding capital control announcements. The next subsection describes the methodology.

\subsection{An event study with stock market data}

We use an event-study methodology to examine investors' reaction to the strengthening or weakening of capital controls. ${ }^{12}$ If capital markets are semi-strong form efficient with respect to public information, stock prices will quickly adjust following an announcement, incorporating any expected value changes (Andrade et al., 2001).

Event studies in finance and economics examine the reaction of asset (stock) prices to public news events (see MacKinlay, 1997 for an excellent survey). In addition, examples of tax applications in event studies are Cutler (1988) to examine the impact of tax reform and stock prices and Auerbach and Hassett (2007) to evaluate the impact of dividend tax cuts on the value of the firm.

Briefly, stock prices are present discounted values of expected future cash flows where the discount rate or cost of capital a firm faces depends on the required rate of return investors demand. Stock price changes in turn reflect changes in discount rates or expected future cash flows. Stock prices fall if discount rates rise or expected future cash flows fall. Conversely, stock prices rise if discount rate fall or expected future cash flows rise. When discount rates and cash flows move in the same direction, they have offsetting effects-whether stock prices rise or falls in that case depends on which effect dominates.

If markets are semi-strong form efficient, security prices will immediately reflect the impact of news such as capital controls taxes. Financial market data therefore offer easily measurable summary statistics that capture the economic impact of news such as changes in policy on firm value over relatively high frequencies. It is important to note that semi-strong form market efficiency also implies that there should be no tendency for systematically positive or negative returns after news events, except to the extent that the events alter assets' compensated risk exposures. It is traditional to assume that events have no effect on such risk exposures implying that the price reaction at the time of the news event (after controlling for other events occurring at the same time) is an estimate of the change in fundamental value of the asset (the expected present value of its dividends, discounted at a constant rate) implied by the news release.

In the case of capital controls announcements, the fundamental value of an asset can change because of either compensated risk exposures (expected returns/discount rates) change as capital controls

\footnotetext{
12 For more details, see MacKinlay (1997).
} 
taxes impose an international investment barrier (price wedge) or because dividends/expected future cash flows change. We attempt to capture the effect of capital controls announcements under the assumption of semi-strong form market efficiency.

Optimally event windows over which news reactions are measured ought to be short so that other news about events does not contaminate the measurement of the market's reaction to the particular news event of interest. Typically, in studies that use daily financial data event windows range from two-three days to twenty-one days. It is important to note that, the stock price reaction or the announcement return in the event window is a summary statistic of expected changes in the present discounted value of cash flows for a given firm over the entire infinite horizon. The connection between stock prices and news therefore creates a link between the present and the future (Henry, 2007).

The benchmark model or the estimation window (280 to 30 days prior to the event) is used to measure the "normal" expected return using the CAPM. Abnormal returns capture the "unexpected news" or announcement effect of the policy change (capital controls). A negative abnormal return implies that either the cost of capital is expected to increase or cash flows (dividends) are expected to decrease. In either case a negative abnormal return (AR) suggests that the market interprets the "news" of capital controls as an adverse event. These abnormal returns are cumulated over the event window to arrive at the cumulative abnormal returns (CARs).

Our benchmark regression analysis cumulates abnormal returns over a two-day window while we corroborate the robustness of our results with alternate event window lengths later in the paper. In particular, we analyze several windows (two, three, five, eleven, and twentyone days) but present results for the two-day windows in our main specifications as this is the most stringent identification test we can apply to capture the announcement effect of the capital controls with less concern about other confounding news events.

Finally, note that if the controls alter the expected value or variance of the domestic production activities, the impact on a firm's stock price will depend on two effects: the expected cash flow effect and the required rate of return or cost of capital effect. A priori, some firms can benefit from the protectionist variety of capital controls. It is possible therefore that for these firms expected cash flows increase more than the rise in the required rate of return such that stock prices rise, and CARs are positive following the imposition of capital controls. For example, exporting firms may benefit from protectionist capital controls if the exchange rate depreciates and expected future cash flows go up.

\section{The data and summary statistics}

We examine the firm-level abnormal stock return adjusted for clustering around windows of time surrounding the announcement of the capital control policy. Stock prices are from Datastream. The market returns used in the benchmark estimations uses the BOVESPA return (the most commonly quoted index in Brazil). We also analyze different broad indices available for different sectors or classes of firms such as the IBRA index. As mentioned in the previous subsection, our estimation period is 280 days before and up until 30 days preceding the event date. Cumulative abnormal returns (CARs) sum the abnormal returns over the event window, with abnormal returns estimated using a market model with Scholes-Williams betas that make adjustments for the noise inherent in daily returns data. ${ }^{13}$ Given that the some of the events are close in time making their estimation windows overlapping in time, we also conduct the analysis using the estimation window prior to the

\footnotetext{
13 In particular, nonsynchronous trading of securities introduces a potentially serious econometric problem of errors in variables to estimate the market model with daily returns data (Scholes and Williams, 1977). To address this problem, Scholes-Williams betas provide computationally convenient and consistent estimators for the market model. Using a standardized value of the cumulative abnormal return, we test the null hypothesis that the return is equal to zero.
}

October 2009 event as the benchmark return in the CAR calculations for all the following events.

Data about firm characteristics are from Worldscope and the sample consists of quarterly data from Q4 2007-Q4 2013. These include the log of total assets, as a proxy for size and debt to total assets, and short-term debt to total debt as proxies for liquidity. ${ }^{14}$ In addition, we construct a number of measures of external finance dependence beginning with the Rajan and Zingales (1998) measure using time-series Brazilian data. We use the consumer price index (CPI) index to deflate the data. The firm-level information is matched to export status and the range of exports using data from the Brazilian Secretary of External Trade (Secretaria de Comercio Exterior, Secex). The export range is in U.S. dollars (FOB) and includes firms exporting less than $\$ 1$ million, between $\$ 1$ million and $\$ 100$ million, and more than $\$ 100$ million. Given that coverage of foreign sales data is very poor in the widely used Worldscope data, access to the proprietary Secex data for exports is a key differentiator of our study.

\subsection{Summary statistics}

Fig. 1 depicts the evolution of the BOVESPA index corresponding to the different capital controls announcements in Table 1 . The table includes the capital controls announcement dates, whether the control affected inflows of debt or equity, the change in the market return on the BOVESPA index in the two-day post-announcement period, and a description of the event. ${ }^{15}$

Table 2 presents firm-level summary statistics for the firms in the BOVESPA index that includes prices for the more actively traded and better representative stocks of the Brazilian stock market. In the robustness analysis, we also examine the stock price reaction for firms listed on the alternative IBRA index. Information includes firm size, exporter status, liquidity, and leverage measures. We report firm size, operating revenue in real terms, i.e., the nominal values deflated by the CPI. The data show that the average firm size regarding log total assets and in real terms. In nominal terms, this roughly translates to US $\$ 10$ million at an average exchange rate of $1.9 \mathrm{R} \$ / \mathrm{US} \$$ over the sample period. The average leverage ratio (debt/assets) is close to $31 \%$ while short-term debt (of less than one year) on average accounts for about $30 \%$ of total debt.

Table 2 also reports summary statistics for log assets and operating revenues for the full sample, exporting, and non-exporting firms Note that non-exporting firms include large utilities and financial services firms such as large banks. About $40 \%$ of the firms in the sample are exporters with half of them belonging to the largest exporting group (more than $\$ 100$ million). Panel B reports summary statistics for exporting firms and suggests that exporting firms are on average slightly larger than non-exporting firms in Panel C. Exporting firms a slightly higher debt-to-assets ratio than non-exporting firms (33\% versus 30\% respectively) and less short-term debt (26\% to $33 \%$ ).

\section{Results}

\subsection{Abnormal returns and firm characteristics}

Before turning to the regression analysis, a visual inspection of our data is useful. To do so Fig. 2a and b graphically present the stock market's response to capital control announcements. The horizontal axis is in event time for four days before and four days after the capital controls announcement dates. Fig. 2a shows the abnormal returns

\footnotetext{
14 Data availability varies across firms. In Brazil, with the exception of media firms, all firms are available to foreign investors. While the government retains some shares in state-owned firms that were privatized such as Petrobras, foreign investment is allowed in these firms.

${ }^{15}$ The table also includes the Decree number associated with the change in the IOF. As mentioned in footnote 9, the table excludes the removal of controls on October 22nd 2008.
} 


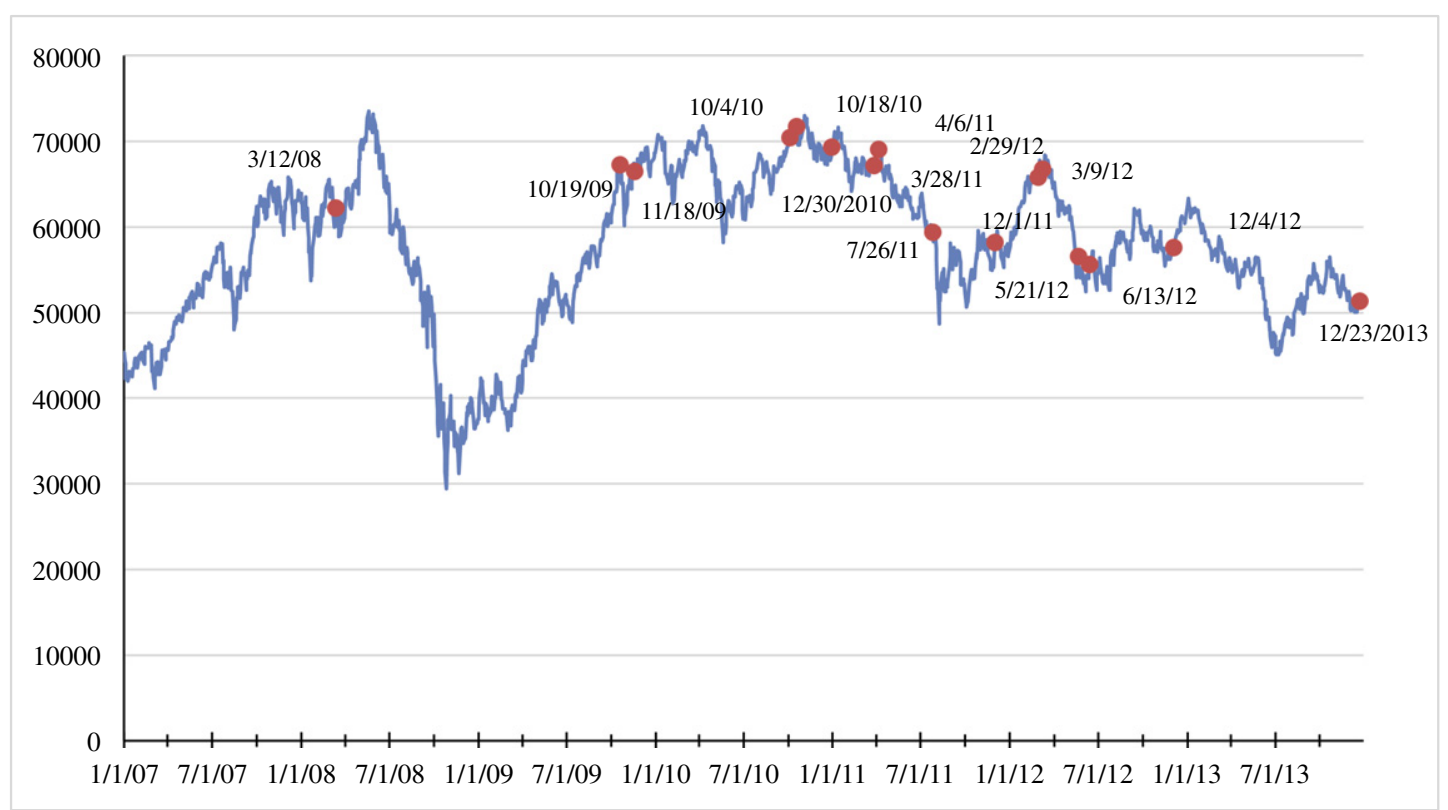

Source: Datastream and authors construction using capital control event dates.

Fig. 1. Brazil's Bovespa and capital control events (daily).

Source: Datastream and authors construction using capital control event dates.

averaged across firms by event. The abnormal returns were first averaged across firms for each event in event time $[t=-3, t=+3]$ and then averaged across events. Fig. $2 \mathrm{~b}$ presents the results cumulated across firms by event and then averaged across events also in event time. Both figures visually confirm that on average in the aftermath of capital controls announcements abnormal returns are negative.

The formal regression analysis in Table 3 uses panel data (by firm and event) where the dependent variable is the firm-specific two-day cumulative abnormal return. The basic regression specification is:

$C A R_{i t}=$ Constant + FirmControls $s_{i t}+\varepsilon_{i t}$,

Table 2

Summary statistics.

Notes: Financial figures are from Q4 2007 which is the last quarter prior to the announcement regarding the introduction of capital controls on 3/12/2008. Summary statistics correspond to benchmark estimation in Table 3. Nominal variables at the firm-level are divided by the Consumer Price Index $(\times 100)$. The sample period is Q4-2007-Q4-2013. Total Assets and Operating Revenue are in real terms deflated by the CPI. The average USD/Reais exchange rate from 2008 to 2013 was 1.897 R \$/US\$.

Sources: Datastream for firm-level data and Secex for export data.

\begin{tabular}{lllll}
\hline & Observations & Mean & Std. dev. & Median \\
\hline Panel A: All firms & & & & \\
Total assets (log) & 1016 & 16.697 & 1.633 & 16.497 \\
Debt/assets (\%) & 1006 & 31.433 & 15.416 & 29.150 \\
Short-term debt/debt (\%) & 928 & 30.137 & 24.102 & 22.774 \\
Operating revenue (millions of R\$) & 1013 & 1.011 & 2.917 & 0.278 \\
Exporter dummy & 1016 & 0.419 & 0.494 & 0.000 \\
Panel B: Exporting firms & & & & \\
Total assets (log) & 426 & 16.781 & 1.590 & 16.872 \\
Debt/assets (\%) & 424 & 32.933 & 16.360 & 29.135 \\
Short-term debt/debt (\%) & 410 & 26.095 & 20.051 & 19.321 \\
Operating revenue (millions of R\$) & 424 & 1.580 & 3.783 & 0.313 \\
Panel C: Non-exporting firms & & & & \\
Total assets (log) & 590 & 16.636 & 1.663 & 16.298 \\
Debt/assets (\%) & 582 & 30.341 & 14.607 & 29.170 \\
Short-term debt/debt (\%) & 518 & 33.335 & 26.464 & 25.109 \\
Operating revenue (millions of R\$) & 589 & 0.601 & 1.987 & 0.266 \\
\hline
\end{tabular}

where $C A R_{i t}$ is the cumulative abnormal return for firm $i$ over the event window $t$. We use a two-day event window as our benchmark specification. The constant term captures the impact of the announcement on average returns, and firm controls include an observable set of firmspecific characteristics such as size, leverage, and so on.

Our methodology is as follows. We construct a CAR for each firm around each event date. We stack the firms to create a panel of firmevent observations. In the benchmark estimation we use both tightening and loosening announcements. Subsequent estimations include a loosening dummy to see if the market responds differentially depending on the direction of the change in capital controls. We also conduct the estimations by including event dummies.

Since the association between abnormal returns and firm characteristics could be explained by other documented regularities, we compute bootstrapped $p$-values of the OLS regression using the method proposed in Busse and Green (2002). The results report the OLS bootstrapped one-tailed $p$-values. ${ }^{16}$

Measures of two-day CARs using Scholes-Williams betas suggest a significant decline in stock returns surrounding the capital control announcements consistent with an increase in the cost of capital for firms listed on the BOVESPA (Table 3, Column 1). Quantitatively CARs fall by about $-0.28 \%$ on average over a two-day window for the full sample of events in Table 1 . The effect is statistically significant at the $1 \%$ level.

Column 2 includes a proxy for firm size in terms of (log) total assets lagged by one quarter. Controlling for size, the coefficient on the constant term suggests that the CARs fall on average by a quantitatively significant $-2.66 \%$ at the $1 \%$ level, which is an order of magnitude higher than the simple regression in Column 1 that does not control for firm size. This suggests that firm size captures an important dimension of underlying heterogeneity at the firm level. The size variable measured by the lagged value of total firm assets has a positive and significant effect on abnormal returns at the $1 \%$ level. The results from the specification in Column 2, suggest that large firms were somewhat shielded from the imposition of capital controls.

${ }^{16}$ Results are robust to using two-way clustered standard errors (available upon request). 


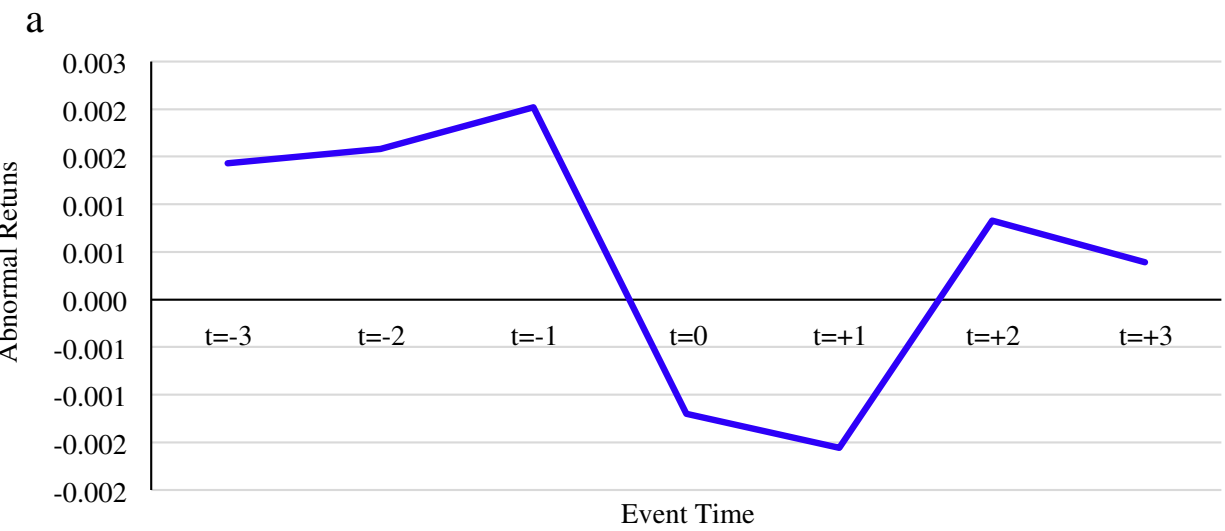

- Average Abnormal Returns

b

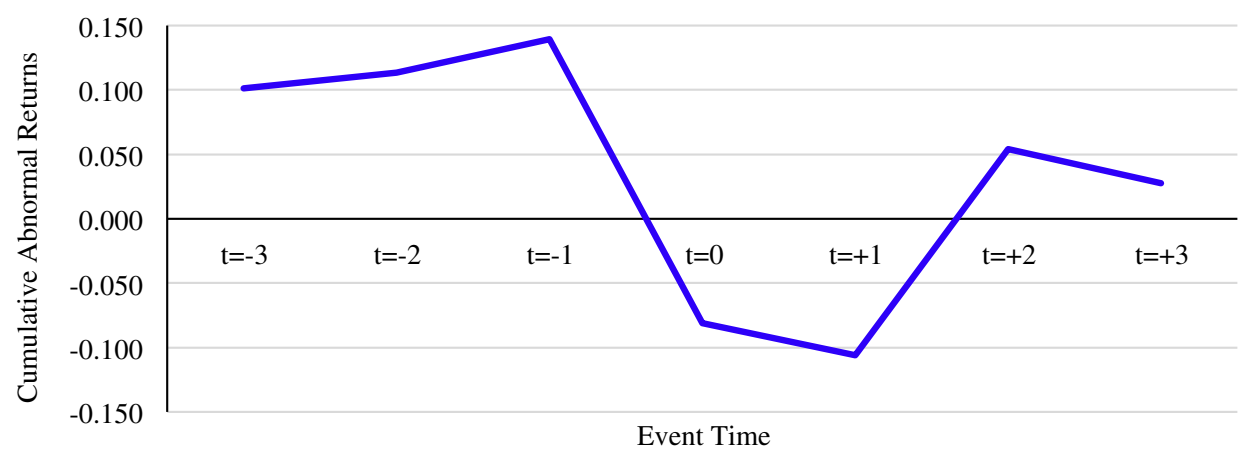

- Average Cumulative Abnormal Returns

Fig. 2. a: Capital control announcements: abnormal returns in event time (daily). b: Capital control announcements: average abnormal returns (cumulated across firms by event).

To get a sense of the quantitative importance of the estimates we further explore the importance of size as a key dimension of underlying firm-level heterogeneity. We examine the effects of a one standard deviation increase in firm size on the magnitude of the CAR. The mean of log assets, our measure of firm size, is 16.69. A firm whose assets are one standard deviation larger than the mean firm has a log asset value of 18.33 (i.e., the logged asset value of a firm with size $(\mu+\sigma)$ ). If we turn to column (2) in Table 3, the coefficient estimates for the mean sized firm give a fitted two-day CAR of $-0.29 \%(-0.0266+$ $\left.0.00142 * \mu_{\log \text { Assets }}\right)$. Similarly, for a firm that is one standard deviation larger than an average-sized firm the fitted two-day CAR equal to $-0.057 \%$. Comparing the two fitted CAR values suggests that a one standard deviation increase in firm size results in a less negative value for the two-day CAR-the difference is about $-80.25 \%$. The net effect of firm size therefore appears quantitatively significant. While the overall effect is still negative for a one standard deviation increase in firm size, the magnitude of the adverse impact appears reduced. As a benchmark for comparison of return magnitudes, the average daily raw return for the sample period is $+0.059 \%$.

The rows at the bottom of Table 3 report the fitted CARs (and standard errors) for firms at P25, P50, the mean, P75, P90 and P95. Consistent with the positive coefficient on log assets, note that the fitted CAR values monotonically increase as we go from the bottom end of the distribution of firm size to the biggest firms. Moreover the signs on the fitted mean CAR values remain negative till the P75 for firm size and become positive for firms with size in the P90 and above suggesting once again that the largest firms were somewhat shielded from the adverse effects of the capital controls policies. Column (2) fitted CAR values in the $95 \%$ confidence interval at P75 range from $[+0.002 \%$,
$-0.39 \%]$. The upper bound of the confidence interval therefore contains marginally positive values. The $95 \%$ confidence interval at P95 ranges from $[+0.57,-0.16 \%]$ suggesting that the lower bound for the very largest firms also contains negative values. Confidence interval ranges for firm sizes below P75 are uniformly negative confirming that the negative burden of capital controls policies appears to disproportionately affect smaller listed firms.

Including controls for leverage, such as debt to total assets in Column 3 and short-term debt to total debt, does not appear to have a significant effect on the abnormal returns. Columns 3 and 4 corroborate that, on average, CARs are significantly negative at the $1 \%$ level, while firm size somewhat mitigates the negative effect on abnormal returns in the immediate aftermath of capital control announcements.

Column 5 includes a variable that takes into account a firm's exporter status. The evidence suggests that the average effect of the capital controls announcement is negative and significant at the $1 \%$ level while the coefficient on exporter status is positive and significant at the 5\% level. Two factors namely internal capital markets and improved competitiveness could have shielded exporting firms from the adverse impact of the controls. First, there could be cross-sectional variation in the cost of capital impact as well as credit constraints depending on firm characteristics. For instance, we saw earlier that large firms may be somewhat shielded from the adverse cost of capital impact. This may be because large firms can rely on internal capital markets or other sources of financing to fund their operations in the aftermath of controls. Similarly, exporting firms, especially the larger firms, may have access to internal capital markets or foreign currency proceeds and therefore, less reliant on foreign capital investments. 
Table 3

Post-capital control announcement returns are significantly negative.

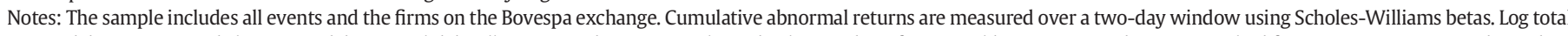

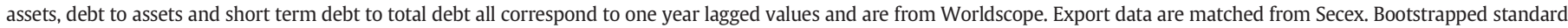
errors in parenthesis.

\begin{tabular}{|c|c|c|c|c|c|c|}
\hline & \multicolumn{6}{|c|}{ Panel A: Cumulative abnormal returns (Scholes-Williams) } \\
\hline & \multicolumn{6}{|c|}{ All events } \\
\hline & (1) & $(2)$ & (3) & $(4)$ & $(5)$ & (6) \\
\hline Constant & $\begin{array}{l}-0.00277^{* * *} \\
(0.0011)\end{array}$ & $\begin{array}{l}-0.0266^{* * *} \\
(0.0078)\end{array}$ & $\begin{array}{l}-0.0263^{* *} \\
(0.0128)\end{array}$ & $\begin{array}{l}-0.0229^{* *} \\
(0.0089)\end{array}$ & $\begin{array}{l}-0.0273^{* * *} \\
(0.0086)\end{array}$ & $\begin{array}{l}-0.0307^{* * * *} \\
(0.0099)\end{array}$ \\
\hline $\begin{array}{l}\text { Log total assets } \\
\text { (lag 1y) }\end{array}$ & & $\begin{array}{l}0.00142^{* * *} \\
(0.0004)\end{array}$ & $\begin{array}{l}0.00133^{*} \\
(0.0007)\end{array}$ & $\begin{array}{l}0.00122^{* *} \\
(0.0005)\end{array}$ & $\begin{array}{l}0.00137^{* * *} \\
(0.0005)\end{array}$ & $\begin{array}{l}0.00158^{* * *} \\
(0.0006)\end{array}$ \\
\hline $\begin{array}{l}\text { Debt/assets } \\
(\operatorname{lag} 1 \mathrm{y})\end{array}$ & & & $\begin{array}{l}0.0000447 \\
(0.0001)\end{array}$ & & & \\
\hline $\begin{array}{l}\text { Short-term debt/debt } \\
\text { (lag 1y) }\end{array}$ & & & & $\begin{array}{l}-0.00171 \\
(0.0043)\end{array}$ & & \\
\hline Exporter & & & & & $\begin{array}{l}0.00376^{* *} \\
(0.0018)\end{array}$ & \\
\hline Export $<\$ 1 \mathrm{mil}$ & & & & & & $\begin{array}{l}-0.00299 \\
(0.0038)\end{array}$ \\
\hline Export $\$ 1$ mil-\$100 mil & & & & & & $\begin{array}{l}0.00765^{\ddagger} \\
(0.0050)\end{array}$ \\
\hline Export $>\$ 100$ mil & & & & & & $\begin{array}{l}0.00258 \\
(0.0021)\end{array}$ \\
\hline Observations & 1078 & 1016 & 1006 & 928 & 1016 & 1016 \\
\hline \multirow[t]{3}{*}{ R-squared } & 0.000 & 0.005 & 0.005 & 0.004 & 0.008 & 0.012 \\
\hline & \multicolumn{6}{|c|}{ Panel B: Fitted CARs and standard errors } \\
\hline & \multicolumn{2}{|c|}{ Column (2) } & \multicolumn{4}{|c|}{ Column (5) } \\
\hline Log total assets & \multicolumn{2}{|c|}{ Size } & \multicolumn{2}{|c|}{ Size and exporter } & \multicolumn{2}{|c|}{ Size and non-exporter } \\
\hline (lag 1y) & Fitted CARs & s.e. & Fitted CARs & s.e. & Fitted CARs & s.e. \\
\hline P25 & -0.0042 & 0.0013 & -0.0017 & 0.0022 & -0.0058 & 0.0010 \\
\hline P50 & -0.0031 & 0.0010 & -0.0004 & 0.0020 & -0.0049 & 0.0010 \\
\hline Mean & -0.0028 & 0.0010 & -0.0005 & 0.0019 & -0.0045 & 0.0010 \\
\hline P75 & -0.0020 & 0.0009 & 0.0005 & 0.0019 & -0.0040 & 0.0011 \\
\hline P90 & 0.0011 & 0.0014 & 0.0028 & 0.0021 & -0.0002 & 0.0022 \\
\hline P95 & 0.0020 & 0.0017 & 0.0034 & 0.0022 & 0.0005 & 0.0025 \\
\hline
\end{tabular}

*** $p<0.01$.

** $p<0.05$.

$* p<0.1$.

$\neq p<0.15$.

Second, to the extent that the controls can curb the currency appreciation and improve the competitiveness of exporting firms, the expected future cash flows of the exporting firms can improve in the aftermath of the controls. ${ }^{17}$ Exporters could be in an improved competitive position internationally, which drives up their expected cash flows and abnormal returns. The second explanation is consistent with the argument that as a by-product of prudential capital controls designed to mitigate the volatility of foreign capital inflows and manage endogenous systemic risk, a depreciated currency may benefit exporting firms in the country imposing the controls. Given that Column 5, includes controls for both firm size and exporter status, the coefficient estimates suggests that large exporting firms are likely to be less negatively affected by the capital controls policy.

Column 6 further explores the impact of the capital controls announcement on exporting firms by size groups. It is interesting to note that smaller exporters in the $<\$ 1$ million revenue bin do not experience significant returns. The coefficients on exporting firms in the $\$ 1-\$ 100$ million revenue bin and the largest revenues, i.e., in the $>\$ 100$ million in revenues are positive and statistically significant at the $15 \%$ level for the second bin suggesting that controlling for firm size, the magnitude of the export revenues may also matter.

\footnotetext{
17 Note that although the policy can in principle tax trade credits, the IOF was set to zero.
} See https://www.receita.fazenda.gov.br/Legislacao/Decretos/2008/dec6339.htm.
The rows below the Table 3 show that the pattern of negative fitted CAR values for the specification in Column 2 (that controls for firm size) holds for firms in all size percentile bins barring the very largest firms in the P95 percentile. The pattern of negative fitted CARs for the specification in Column 5 (that controls for size and exporter status) holds for exporters in all size bins except for the largest exporters in the P90 and above size category. For non-exporters, we report negative fitted CARs for all size bins including the very largest firms. Overall, the evidence suggests that large firms with large export revenues are somewhat shielded from the negative effects of capital controls announcements.

A stated goal of the controls was to protect the tradable firms from being hurt by an overvalued exchange rate. Therefore some may argue that the net effect of the controls for an exporting firm is a positive CAR, at the expense of a negative CAR for non-exporting firms is a welcome distributional development of the policy (equivalent to "taxing" some firms to "subsidize" exporters). However, our results suggest that it is the large firms and large, exporting firms that are the less adversely affected by the capital controls policies-in fact, the estimated coefficients suggest that the overall impact on fitted CARs are positive and significant for the largest firms and the largest exporters. In a developing country like Brazil, it is not clear how subsidizing large exporters at the expense of taxing small firms including smaller exporters and in particular small, non-exporters would be viewed as a desirable. We therefore take the view that the net positive effects on large firms and large exporters are an unintended consequence of the capital controls policies. 
Also note that systematic firm-level financial data for small, unlisted firms are not available for these Brazilian firms. Disclosure requirements for listed firms provide access to firm-level financial statements. Further, our empirical methodology relies on estimating cumulative abnormal returns based on stock market data that are also only available for firms that are listed on the stock market. Our results show that from the listed sample, the firms that are most adversely affected are the small, non-exporters. This evidence therefore also suggests that our results may suffer from attenuation bias in that we do not have the smallest, unlisted firms in the sample. In some sense one can argue that our evidence provides a lower bound estimate of the adverse impact of capital controls on the cost of capital for Brazilian firms.

\subsection{Credit constraints and abnormal returns}

Next, we examine the hypothesis of credit constraints and external finance dependence. Moving beyond the overall cost of capital, there is another factor to consider in the context of liquidity or creditconstrained firms. Here, the distinction between the differential cost of external and internal finance can also play a role. By affecting the cost of external finance, the imposition of capital controls could affect firms that are more dependent on external finance to fund their investment opportunities. The test then is whether firms (or industries) dependent on external finance are more adversely affected by capital controls as measured by the market's reaction to the policy announcement. Consistent with arguments in Rajan and Zingales (1998), there are two advantages to this simple test: it focuses on the mechanism by which the cost of finance affects a firm's growth prospects, thus providing a stronger test of causality, and it can correct for industry effects.

Moreover, liquidity constraints at the firm level may depend on external finance dependence, firm size, and export status. Firms with easier access to external finance or greater access to low-cost funds may be able to overcome the barriers associated with any fixed costs of production (Chaney, 2013). To proxy for a firm's dependence on external finance, we measure the extent of investment expenditures that cannot be financed through internal cash flows generated by the firm using time-series Brazilian data. In other words, we construct the Rajan and Zingales (1998) external finance dependence measure using Brazilian firm data. Accordingly, a firm's dependence on external finance is defined as capital expenditures minus cash flow from operations divided by capital expenditures. Table 4 presents the results.

Column 1 of Table 4 (Panel A) shows the benchmark regression, which includes controls for firm size, exporter status, and external finance dependence. Consistent with the hypothesis that firms that are more dependent on external finance may be affected adversely by capital controls, the coefficient on the external finance dependence variable is negative and significant at the $1 \%$ level. Average CARs are negative and significant, but firm size and exporter status-consistent with results in previous tables-have positive and significant coefficients.

Panel B of Table 4 reports fitted CARs for the results in column 1 conditioning on external finance dependence, size and exporter status. The fitted CARs suggest that conditioning on size, exporters with high external finance dependence (P75) have a significantly more negative CAR compared to exporters with median (P50) external finance dependence. For non-exporters the fitted CARs are consistently more negative across external finance bins. For example in the high external finance (P75) bin, the fitted CAR value for exporters is $-0.37 \%$ while it is $-0.63 \%$ for non-exporters over the two-day event window.

Column 2 of Panel A disaggregates exporting firms by the size of their exporting revenues. External finance dependence continues to have a negative and significant effect on abnormal returns. The evidence also suggests that while the smallest exporters (with revenues less than
$\$ 1$ million) are negatively affected, the larger exporters appear to be somewhat shielded.

Columns 3-8 examine different measures for external finance dependence. Columns 3 and 4 include a dummy variable to distinguish between firms with high and low finance dependence relative to the mean. Columns 5 and 6 restrict the sample to manufacturing firms and classify them according to high and low external finance dependence following the Rajan and Zingales (1998) classification. The result that external finance dependence has a negative and significant effect of abnormal returns is robust to these alternative measures. Turning to the quantitative significance of the coefficients in Panel B of Table 4, we see that for firm's with an external finance dependence that exceeds the mean, the median sized non-exporters (P50) are affected more adversely than the larger non-exporters (P75) with fitted CARs of $-0.62 \%$ and $-0.57 \%$, respectively. Large exporters (P75) have positive fitted two-day CARs across external finance dependence measures above and below the mean. Manufacturing firms with high external finance dependence are affected more adversely for both exporters and non-exporters at the P50 and P75 size percentiles.

Also, note that in the economy, some firms rely more on equity financing (relative to debt financing) than others. This is reflected, for example, in the substantial degree of variation in leverage across sectors. Given that some events impose controls on debt inflows while other events impose control on equity inflows, it is interesting to analyze whether firms that rely more on equity financing are affected more by equity controls, and firms that rely more on debt financing are affected more by debt controls.

To do so, we constructed a measure of equity dependence following the Rajan and Zingales measure as the amount of common equity as a fraction of total capital expenditures. The results suggest that the cumulative abnormal returns are inversely correlated with the equity finance dependence but not in a statistically significant manner (Table 4, Columns 7 and 8).

\subsection{Debt versus equity events}

Firms rely on both debt and equity financing. The overall cost of capital embodies the risk-free rate (based on debt instruments) and the equity premium. If the tax on debt instruments drives up the riskfree rate or implicitly the average cost of capital, the cost of capital increases and holding expected future cash flows constant, drives down the stock price manifested in negative firm-level CARs. We therefore expect that the stock market could react to controls on debt instruments as well as equity instruments.

The recent Brazilian capital controls differentiate between debt and equity related measures. Table 5 displays regression specifications that include a dummy variable that takes a value of one for equity events and zero for debt-related controls events. The pattern of results holds with highly significant negative CARs when capital control measures are announced. The coefficient on the constant is significant at the $1 \%$ level, controlling for size and exporter status (Columns 1 and 2). The equity dummy is negative and statistically significant at the $5 \%$ level. Controls on equity flows display a more negative announcement effect compared to controls on debt. A similar pattern obtains in Columns 3 and 4 that include controls for external finance dependence.

Fitted CARs in Panel B show that for equity-related controls, exporters in all size percentiles with the exception of the 95thpercentile are negative ranging from $-0.46 \%$ for the smallest exporters (P25) to $-0.01 \%$ for the larger exporters (P90). The magnitude of the negative CARs declines as we go from the 25th-percentile to the 90thpercentile of firm size. For non-exporters, the magnitude of negative CARs is much higher ranging from $-0.88 \%$ for the smallest (P25) to $-0.24 \%$ for the largest (P95) non-exporters for equity related controls. For debt-related controls, while the smallest exporters are marginally negatively affected, exporters in all other size bins display positive CARs ranging from $0.13 \%$ to $0.51 \%$. For non-exporters, all but the largest 
Table 4

External finance-dependent firms are more negatively impacted by capital controls.

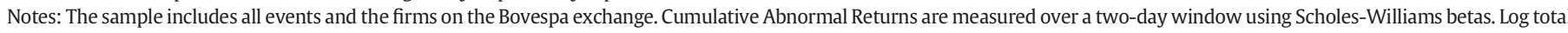

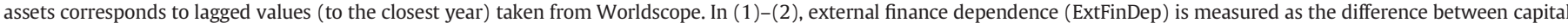

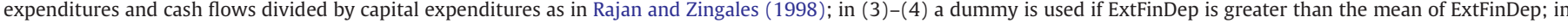

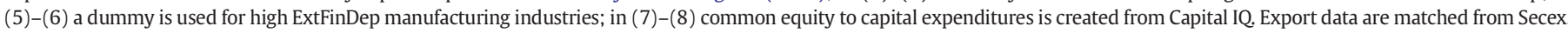
Bootstrapped standard errors.

Sources: Datastream, Capital IQ and Secex.

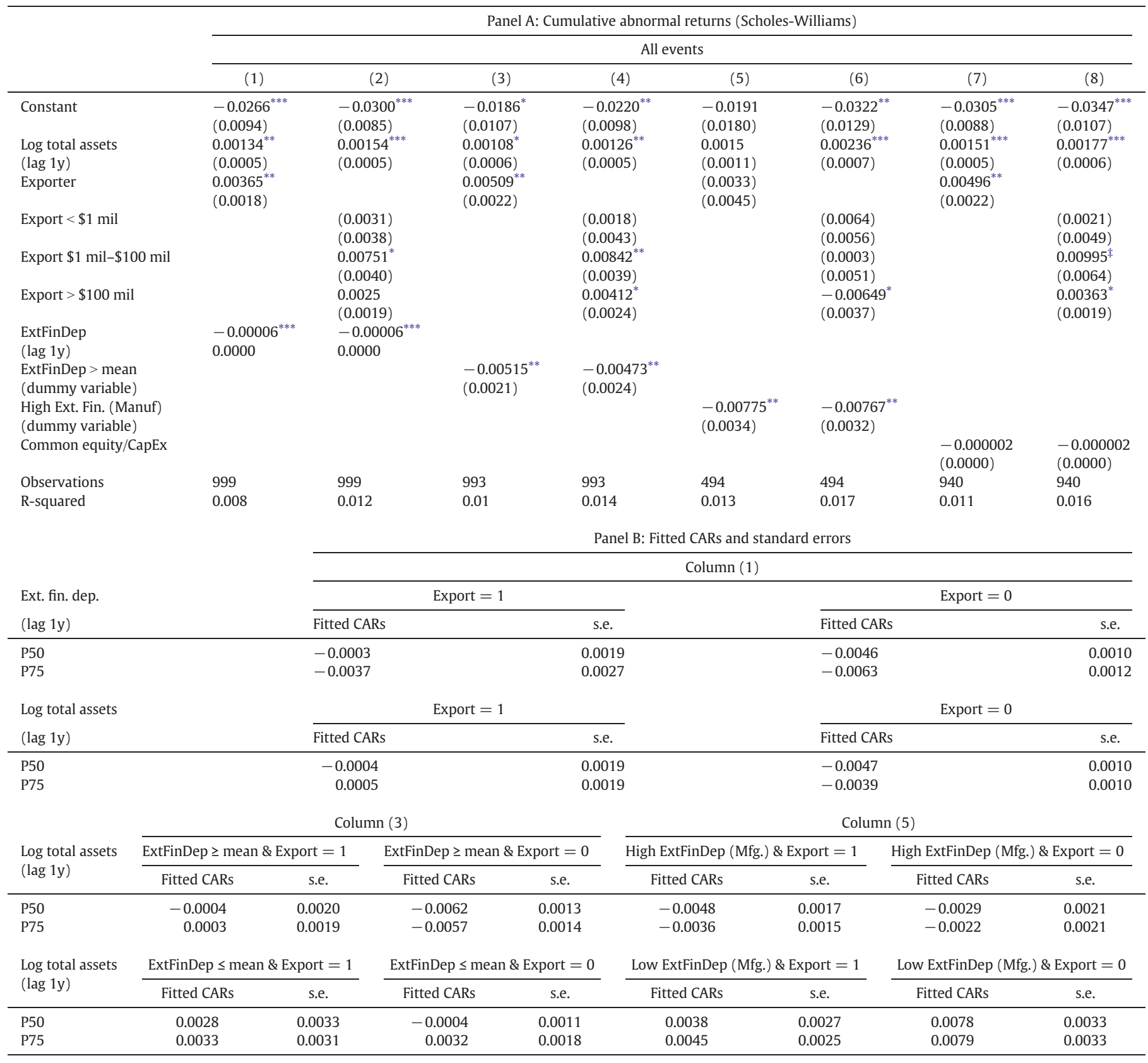

*** $p<0.01$.

** $p<0.05$.

$* p<0.1$.

$¥ p<0.15$.

exporters ( $>$ P90) display negative fitted two-day CARs ranging from $-0.41 \%$ to $-0.25 \%$.

There are two explanations that can help interpret the result that controls on equity are associated with significantly more negative CARs than controls on debt. The first explanation relates to the fact that while Brazil historically experimented with the IOF tax exclusively on debt flows such as in the 1990s, extending the purview to include equity instruments was done for the very first time in October 2009 (see
Goldfajn and Minella, 2007). The market's reaction may, therefore, be capturing the element of surprise or unexpected nature of the policy change to include equity flows.

Second, controls on debt flows may serve to reduce financial vulnerability given that debt is a non-contingent claim that can generate systemic risk. Since debt does not embody the risk-sharing aspects of international equity flows, excessive reliance on external debt (especially foreign-currency denominated bank loans that generate 
Table 5

The market reaction is different for controls on debt vs. equity.

Notes: The sample includes all events and the firms on the Bovespa exchange. Cumulative abnormal returns are measured over a two-day window using Scholes-Williams betas. Log total assets correspond to one year lagged values from Worldscope. External finance dependence (ExtFinDep) is measured as the difference between capital expenditures and cash flows divided by capital expenditures as in Rajan and Zingales (1998). Export data are matched from Secex. Equity is a dummy for equity events. Bootstrapped standard errors in columns (1)-(4).

\begin{tabular}{|c|c|c|c|c|}
\hline & $(1)$ & $(2)$ & (3) & $(4)$ \\
\hline & \multicolumn{4}{|c|}{ Panel A: Cumulative abnormal returns (Scholes-Williams) } \\
\hline & \multicolumn{4}{|c|}{ All events } \\
\hline Constant & $\begin{array}{l}-0.0258^{* * *} \\
(0.0099)\end{array}$ & $\begin{array}{l}-0.0292^{* * *} \\
(0.0087)\end{array}$ & $\begin{array}{l}-0.0251^{* * *} \\
(0.0091)\end{array}$ & $\begin{array}{l}-0.0285^{* * *} \\
(0.0088)\end{array}$ \\
\hline Log total assets & $0.00137^{* *}$ & $0.00158^{* * *}$ & $0.00134^{* *}$ & $0.00154^{* * *}$ \\
\hline (lag 1y) & $(0.0006)$ & $(0.0005)$ & $(0.0006)$ & $(0.0005)$ \\
\hline $\begin{array}{l}\text { ExtFinDep } \\
\text { (lag 1y) }\end{array}$ & & & $\begin{array}{l}-0.00006^{* *} \\
(0.0000)\end{array}$ & $\begin{array}{l}-0.00006^{* *} \\
(0.0000)\end{array}$ \\
\hline Exporter & $0.00387^{*}$ & & $0.00375^{\ddagger}$ & \\
\hline (lag 1y) & $(0.0021)$ & & $(0.0023)$ & \\
\hline Export $<\$ 1$ mil & & $\begin{array}{l}-0.00283 \\
(0.0049)\end{array}$ & & $\begin{array}{l}-0.00297 \\
(0.0040)\end{array}$ \\
\hline Export \$1 mil-\$100 mil & & $\begin{array}{l}0.00778^{*} \\
(0.0046)\end{array}$ & & $\begin{array}{l}0.00762^{*} \\
(0.0046)\end{array}$ \\
\hline Export $>\$ 100 \mathrm{mil}$ & & $\begin{array}{l}0.00268 \\
(0.0022)\end{array}$ & & $\begin{array}{l}0.00259 \\
(0.0017)\end{array}$ \\
\hline Equity & $\begin{array}{l}-0.00449^{* *} \\
(0.0020)\end{array}$ & $\begin{array}{l}-0.00449^{* *} \\
(0.0018)\end{array}$ & $\begin{array}{l}-0.00434^{*} \\
(0.0022)\end{array}$ & $\begin{array}{l}-0.00434^{* *} \\
(0.0020)\end{array}$ \\
\hline Observations & 1016 & 1016 & 999 & 999 \\
\hline R-squared & 0.012 & 0.016 & 0.011 & 0.015 \\
\hline
\end{tabular}

Panel B: Fitted CARs and standard errors

\begin{tabular}{|c|c|c|c|c|}
\hline \multirow{3}{*}{$\begin{array}{l}\text { Log total assets } \\
\text { (lag 1y) }\end{array}$} & \multicolumn{4}{|c|}{ Column (1) } \\
\hline & \multicolumn{2}{|c|}{$\underline{\text { Equity }=1 \& \text { export }=1}$} & \multicolumn{2}{|c|}{ Equity $=1 \&$ Export $=0$} \\
\hline & Fitted CARs & s.e. & Fitted CARs & s.e. \\
\hline P25 & -0.0046 & 0.0018 & -0.0088 & 0.0017 \\
\hline P50 & -0.0033 & 0.0016 & -0.0079 & 0.0017 \\
\hline Mean & -0.0033 & 0.0016 & -0.0074 & 0.0018 \\
\hline P75 & -0.0023 & 0.0015 & -0.0069 & 0.0019 \\
\hline P90 & -0.0001 & 0.0015 & -0.0028 & 0.0027 \\
\hline P95 & 0.0006 & 0.0015 & -0.0024 & 0.0027 \\
\hline \multirow{2}{*}{$\begin{array}{l}\text { Log total assets } \\
\text { (lag 1y) }\end{array}$} & \multicolumn{2}{|c|}{ Equity $=0$ \& Export $=1$} & \multicolumn{2}{|c|}{ Equity $=0$ \& Export $=0$} \\
\hline & Fitted CARs & s.e. & Fitted CARs & s.e. \\
\hline P25 & -0.0001 & 0.0026 & -0.0041 & 0.0013 \\
\hline P50 & 0.0013 & 0.0023 & -0.0034 & 0.0013 \\
\hline Mean & 0.0012 & 0.0023 & -0.0029 & 0.0012 \\
\hline P75 & 0.0021 & 0.0021 & -0.0025 & 0.0012 \\
\hline P90 & 0.0044 & 0.0018 & 0.0010 & 0.0016 \\
\hline P95 & 0.0051 & 0.0018 & 0.0021 & 0.0019 \\
\hline
\end{tabular}

*** $p<0.01$.

** $p<0.05$.

$* p<0.1$.

$\stackrel{\ddagger}{\ddagger}<<0.15$.

currency mismatches on balance sheets) can cause financial distress as we have seen in many an emerging-market crisis. Therefore, the market may perceive controls on debt as a desirable means to curb systemic risk or perform a macro-prudential function with respect to the stability of the financial system.

We also implemented regression specifications (not reported) with (i) an equity event dummy, external finance dependence and an interaction term between equity finance dependence and the equity event dummy and (ii) a debt event dummy, debt finance dependence measured by leverage as well as a debt financing as a fraction of capital expenditures and an interaction term. While the coefficient on the equity finance dependence is negative and significant, the interaction term is not significant. In contrast for debt dependence, the debt finance measure is not significant while the interaction term is negative and significant.
We interpret these results as providing corroborative evidence for our main results about the inverse relationship between CARs surrounding capital control announcements and the external finance dependence characteristic of firms. However, these additional results must be interpreted with caution, for, given the number of events, the power of these tests is not very high. An additional caveat is that some events were applied to both debt and equity instruments and, therefore, may be interfering with clean identification when the dummy variables (equity event, debt event) are included in a pooled regression setting.

The results in Tables 3-5 perhaps also suggest that the market views the implementation of capital controls as being in a different or new "capital-controls regime". Given the variation in the instruments that fell under the purview of these controls, the fact that they were put on (March 2008), taken off (October 2008), put on again (October 2009) and taken off again (2012) and the consistently robust negative and significant CARs across a broad range of specifications suggests that overall the market views these policy changes negatively.

\subsection{Identifying the mechanism}

The evidence suggests that the decline in CARs following the capital control announcements is consistent with an increase in the cost of capital. To provide corroborating evidence we examine the change in the market interest rates in response to capital controls announcements as a mechanism through which there is an increase in the economywide cost of capital. Data on daily interest rates for the one-year, twoyear and five-year interest rates are from Bloomberg.

Table $6 \mathrm{~A}$ presents pooled regressions across the events to quantify the impact on interest rates over a two-day and three day window relative to the day before the announcement. While we find evidence of an increase in market rates ( 3.25 basis points) at the one-year horizon the effects are much stronger in magnitude for the five-year interest rates. The regression estimates suggest that on average five-year market interest rates rise by 11.8 basis points. The increase is statistically significant at the $5 \%$ level of significance. The more muted response of the one-year rate may be the result of it being a direct instrument of monetary policy or the policy rate. The term-structure effects are however more direct measures of the market's response to the unexpected capital controls announcements. It is worth noting that these interest rates increase against the backdrop of quantitative easing in the US and other developed countries that put downward pressure on the world interest rate.

Additionally, Hail and Leuz (2009) present an implied cost of capital methodology using various techniques of accounting-based models of the clean-surplus relation. We follow their methodology and use the modified price-earnings growth (PEG) ratio model by Easton (2004) as the basis for analysis. Here,

$P_{t}=\frac{\hat{x}_{t+2}+r_{P E G} * \hat{d}_{t+1}-\hat{x}_{t+1}}{r_{P E G}^{2}}$,

where:

$P_{t} \quad$ is each firm's stock price on the day of the event, obtained from Datastream.

$\hat{x}_{t+1} \quad$ is each firm's forecasted EPS for the year after the event, obtained from IBES.

$\hat{x}_{t+2}$ is each firm's forecasted EPS for two years after the event, obtained from IBES.

$\hat{d}_{t+1} \quad$ is each firm's forecasted DPS (dividends per share) for the year after the event, obtained from IBES.

$r_{P E G} \quad$ is each firm's estimated cost of capital, for which we solve.

Since our data varies by firm and by event, we have a maximum of $69 * 15=1035$ unique observations. We obtained data from IBES calculated EPS forecasts for three different-length windows both before 
Interest rates, exchange rates, and cost of capital post-capital control announcements.

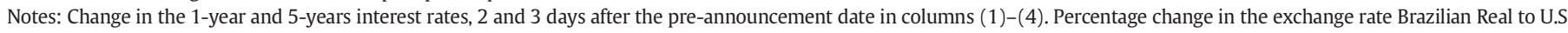
dollar at 2 and 3 days after announcement date in columns (5)-(6). Robust standard errors in parenthesis.

Sources: BM\&F, Bovespa, and Bloomberg.

\begin{tabular}{|c|c|c|c|c|c|c|}
\hline \multicolumn{7}{|c|}{ Changes in interest rates and exchange rate post-capital control announcements } \\
\hline & (1) & $(2)$ & (3) & $(4)$ & (5) & (6) \\
\hline & \multicolumn{4}{|c|}{ Interest rates } & \multicolumn{2}{|c|}{ Exchange rate } \\
\hline & 1 -year & 1-year & 5-year & 5-year & $\%$ change & $\%$ change \\
\hline & $\overline{[t-1, t+2]}$ & $\overline{[t-1, t+3]}$ & $\overline{[t-1, t+2]}$ & $\overline{[t-1, t+3]}$ & {$[\mathrm{t}+2]$} & {$[t+3]$} \\
\hline & All Events & & & & & \\
\hline Constant & $\begin{array}{l}0.0095 \\
(0.0369)\end{array}$ & $\begin{array}{l}0.0325^{* * *} \\
(0.0444)\end{array}$ & $\begin{array}{l}0.0724^{\ddagger} \\
(0.0455)\end{array}$ & $\begin{array}{l}0.118^{\text {*** }} \\
(0.0540)\end{array}$ & $\begin{array}{l}-0.00256^{*} \\
(0.0034)\end{array}$ & $\begin{array}{l}-0.000687 \\
(0.0035)\end{array}$ \\
\hline Obs. & 16 & 16 & 16 & 16 & 16 & 16 \\
\hline
\end{tabular}

*** $p<0.01$

** $p<0.05$

$* p<0.1$.

$¥ p<0.15$.

and after the event, leading to six different observations per firm-event. Post-event windows, we have 14,21, and 28-day windows. All forecasts that were made on the event date or up to 14,21 or 28 days after the event are considered in our analysis. If there are multiple forecasts for a firm-event, they are averaged. For the pre-event window estimates, forecasts made on the day of the event are not considered, but those made up to 14,21 , or 28 days before the event are considered. Once again, if there are multiple forecasts for a firm-event, they are averaged. Separate results were also calculated deflating the forecasts by the CPI of the quarter the forecast is for. Brazilian CPI data were collected from the Brazilian Central Bank.

To solve for estimated cost of capital, we use the quadratic formula:

$$
\begin{aligned}
& P_{t}^{*} r_{P E G}^{2}=\hat{x}_{t+2}+r_{P E G}{ }^{*} \hat{d}_{t+1}-\hat{x}_{t+1} \\
& P_{t} r_{P E G}^{2}-\hat{d}_{t+1} r_{P E G}+\left(\hat{x}_{t+1}-\hat{x}_{t+2}\right)=0 \\
& r_{P E G}=\frac{-b \pm \sqrt{b^{2}-4 a c}}{2 a}, \\
& c=\left(\hat{x}_{t+1}-\hat{x}_{t+2}\right) \\
& a=P_{t} \text {, }
\end{aligned}
$$

$b=-\hat{d}_{t+1}$,

Since the quadratic equation yields two roots, Eqs. (3a) and (3b), roots were classified into two groups: minimum and maximum. Both were used in the estimation.

We conduct the analysis in two steps. First, we compute the cost of capital before and after the event using the earnings forecasts from IBES for 14, 21, 28 day windows before and after the event. We conducted a simple $t$-test of means and find that the cost of capital is significantly higher at the $10 \%$ level in the 14-day window for both the maximum and minimum root values.

Second, to test whether the cost of capital increases after the event, we ran a series of regression specifications with the cost of capital as the dependent variable calculated with data from the 14,21 , and 28-day windows with both maximum and minimum root values. Table 6B shows the results. The results in Columns 3 to 8 show that the post-event dummy is positive and statistically significant at the $10 \%$ level of significance. The specifications control for both firm size

\section{Table 6B}

\begin{tabular}{|c|c|c|c|c|c|c|c|c|}
\hline & $(1)$ & (2) & (3) & (4) & (5) & (6) & (7) & (8) \\
\hline & \multicolumn{8}{|c|}{ Cost of capital } \\
\hline & \multicolumn{2}{|c|}{ Max (14 days) } & \multicolumn{2}{|c|}{ Min (14 days) } & \multicolumn{2}{|c|}{ Max (21 days) } & \multicolumn{2}{|c|}{ Min (21 days) } \\
\hline Constant & $\begin{array}{c}-0.299 \\
(0.730)\end{array}$ & $\begin{array}{c}-0.477 \\
(0.865)\end{array}$ & $\begin{array}{l}-0.252^{\text {**** }} \\
(0.739)\end{array}$ & $\begin{array}{l}-0.439^{* * *} \\
(0.872)\end{array}$ & $\begin{array}{l}-0.203 \\
(0.664)\end{array}$ & $\begin{array}{c}-0.371 \\
(0.786)\end{array}$ & $\begin{array}{c}-0.113 \\
(0.664)\end{array}$ & $\begin{array}{c}-0.276 \\
(0.781)\end{array}$ \\
\hline $\begin{array}{l}\text { Log total assets } \\
\text { (lag 1y) } \\
\text { Exporter }\end{array}$ & $\begin{array}{c}0.0701 \\
(0.051) \\
-0.398 \\
(0.281)\end{array}$ & $\begin{array}{l}0.081 \\
(0.059)\end{array}$ & $\begin{array}{l}0.0682 \\
(0.051) \\
-0.401 \\
(0.291)\end{array}$ & $\begin{array}{l}0.0796 \\
(0.059)\end{array}$ & $\begin{array}{l}0.0605 \\
(0.045) \\
-0.346^{\ddagger} \\
(0.237)\end{array}$ & $\begin{array}{l}0.0706 \\
(0.052)\end{array}$ & $\begin{array}{c}0.0559 \\
(0.044) \\
-0.347 \\
(0.245)\end{array}$ & $\begin{array}{l}0.0657 \\
(0.051)\end{array}$ \\
\hline Export $<\$ 1 \mathrm{mil}$ & & $\begin{array}{l}0.0625 \\
(0.577)\end{array}$ & & $\begin{array}{l}0.0633 \\
(0.591)\end{array}$ & & $\begin{array}{l}0.119 \\
(0.564)\end{array}$ & & $\begin{array}{l}0.135 \\
(0.580)\end{array}$ \\
\hline Export $\$ 1 \mathrm{mil}-\$ 100 \mathrm{mil}$ & & $\begin{array}{l}-0.455^{\ddagger} \\
(0.299)\end{array}$ & & $\begin{array}{l}-0.448 \\
(0.313)\end{array}$ & & $\begin{array}{l}-0.398 \\
(0.259)\end{array}$ & & $\begin{array}{l}-0.397^{\ddagger} \\
(0.269)\end{array}$ \\
\hline Export $>\$ 100 \mathrm{mil}$ & & $\begin{array}{l}-0.503^{*} \\
(0.305)\end{array}$ & & $\begin{array}{l}-0.517^{*} \\
(0.314)\end{array}$ & & $\begin{array}{c}-0.448^{*} \\
(0.256)\end{array}$ & & $\begin{array}{c}-0.452^{*} \\
(0.263)\end{array}$ \\
\hline Post-event dummy & $\begin{array}{l}0.0687 \\
(0.050)\end{array}$ & $\begin{array}{l}0.0674 \\
(0.049)\end{array}$ & $\begin{array}{l}0.0740^{*} \\
(0.044)\end{array}$ & $\begin{array}{l}0.0724^{*} \\
(0.042)\end{array}$ & $\begin{array}{l}0.0590^{*} \\
(0.034)\end{array}$ & $\begin{array}{l}0.0626^{*} \\
(0.034)\end{array}$ & $\begin{array}{l}0.0612^{*} \\
(0.033)\end{array}$ & $\begin{array}{l}0.0649^{*} \\
(0.033)\end{array}$ \\
\hline Observations & 913 & 913 & 878 & 878 & 1050 & 1050 & 1010 & 1010 \\
\hline R-squared & 0.017 & 0.023 & 0.017 & 0.023 & 0.017 & 0.023 & 0.016 & 0.022 \\
\hline
\end{tabular}

Interest rates, exchange rates, and cost of capital post-capital control announcements.

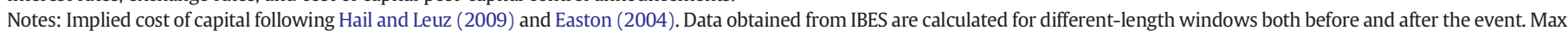

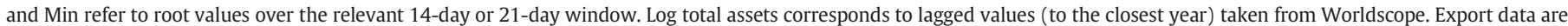
matched from Secex. Clustered standard errors in parenthesis.

*** $p<0.01$.

** $p<0.05$.

$* p<0.1$.

$¥ p<0.15$ 
and exporter status and suggest that the cost of capital goes up significantly following capital control announcements. The post-event dummy is positive but not statistically significant in the 28-day window (not reported). The evidence also suggests that the effects of announcements are smaller for exporting firms.

To see how the exchange rate reacts to the capital control announcements we use daily Real/dollar exchange rate data from Bloomberg. Columns (7) and (8) in Table 6A show the results. The coefficients on the exchange rate variable are negative but not statistically significant. A negative coefficient suggests exchange rate depreciation consistent with the motivation behind capital controls to curb currency appreciation by stemming the inflow of foreign capital. However, the lack of statistical significance precludes us from drawing robust inference from the result.

It is worth noting that over the sample period during which the capital controls were imposed, the Real steadily appreciated between January 2007 and July 2008 and, despite a brief period of depreciation during the onset of the Global Financial crisis, continued to appreciate between January 2009 and July 2011. By the first quarter of 2011, the exchange rate stood at R \$1.6 against the U.S. dollar, and Mantega, Brazil's finance minister, blamed the currency appreciation on incoming foreign capital originating in developed markets. In particular, he focused his criticism on the United States, citing that quantitative easing spurred an excessive influx of foreign capital into Brazil. Mantega stated, "The advanced countries are still running expansionist monetary policies.... The developed world is taking longer to recover than expected and this means their currencies are still devaluing, which is causing the overvaluation of the Real."

An alternative view amongst international policy makers conjectured the onset of the "currency wars" on China's undervalued currency that had an adverse impact on the export prospects of other countries. For example, the Western Hemisphere Director for the IMF, Nicholas Eyzaguirre suggested, "There is a correlation [between] the fact that China pegs its currency and pressures on the exchange rate of Brazil or Peru." The preceding arguments suggest that while the imposition of controls may have been motivated by trying to stem the appreciation of the Real by curbing the inflow of foreign capital from developed countries such as the United States, alternative international economic forces such as the undervalued Renminbi may have rendered such attempts unsuccessful.

\subsection{Robustness checks and additional tests}

We conduct a number of tests to ensure the robustness of our results. The firm and stock market regressions are estimated for different windows and different methodologies for computing returns (raw returns, CAPM) obtaining similar patterns (Table 7) and for firms listed on the alternative IBRA stock exchange (Table 7). Note that the correlations between the betas such as Scholes-Williams, standard CAPM, and so on are very high. The results remain robust.

To the extent that capital controls can drive up the aggregate cost of capital, the cost of bank financing could also increase affecting small firms that rely exclusively on bank financing. To examine whether the source of external financing matters, we control for the share of debt from banks (Table 8, Panel A, Column 1). The coefficient on the variable measuring the share of debt by banks is negative but not significant. Column 2 in Table 8, Panel A reports the results for operating revenue as a proxy for size. The negative CAR result is robust, and the coefficient on operating revenues is positive and significant at the $15 \%$ level. The results are also not driven by the IPO of OGX Petróleo e Gás Participações S.A. or this firm in particular (not reported).

Table 7

Robustness: capital controls, alternative indices, and event windows.

Notes: Cumulative abnormal returns using Scholes-Williams betas, CAPM, and raw returns. Results for BOVESPA and IBRA indices. Bootstrapped standard errors.

Source: Datastream.

\begin{tabular}{|c|c|c|c|c|c|c|}
\hline \multirow[t]{3}{*}{ Returns } & \multicolumn{3}{|c|}{ BOVESPA } & \multicolumn{3}{|c|}{ IBRA } \\
\hline & \multicolumn{3}{|c|}{ CAR } & \multicolumn{3}{|c|}{ CAR } \\
\hline & Scholes-Williams & CAPM & RAW & Scholes-Williams & CAPM & RAW \\
\hline \multicolumn{7}{|c|}{ Panel A: All events } \\
\hline 2 day & $\begin{array}{l}-0.00277^{* *} \\
(0.0011)\end{array}$ & $\begin{array}{l}-0.00294^{* * *} \\
(0.0010)\end{array}$ & $\begin{array}{l}-0.00350^{* * *} \\
(0.0012)\end{array}$ & $\begin{array}{l}-0.00269^{* * *} \\
(0.0008)\end{array}$ & $\begin{array}{l}-0.00297^{* * *} \\
(0.0007)\end{array}$ & $\begin{array}{l}-0.00168^{* *} \\
(0.0007)\end{array}$ \\
\hline 2 day (prior) & $\begin{array}{l}0.000867 \\
(0.0012)\end{array}$ & $\begin{array}{l}-0.00121 \\
(0.0010)\end{array}$ & $\begin{array}{l}0.0106^{* * *} \\
(0.0012)\end{array}$ & $\begin{array}{l}0.00197^{* * *} \\
(0.0006)\end{array}$ & $\begin{array}{l}-0.000804 \\
(0.0006)\end{array}$ & $\begin{array}{l}0.0106^{* * *} \\
(0.0007)\end{array}$ \\
\hline 3 day & $\begin{array}{l}-0.000706 \\
(0.0013)\end{array}$ & $\begin{array}{l}-0.00225^{*} \\
(0.0013)\end{array}$ & $\begin{array}{l}0.00621^{* * * *} \\
(0.0014)\end{array}$ & $\begin{array}{l}-0.000279 \\
(0.0008)\end{array}$ & $\begin{array}{l}-0.00240^{* * *} \\
(0.0009)\end{array}$ & $\begin{array}{l}0.00667^{* * *} \\
(0.0009)\end{array}$ \\
\hline Observations & 1078 & 1078 & 1078 & 2029 & 2029 & 2029 \\
\hline \multicolumn{7}{|c|}{ Panel B: Debt events } \\
\hline 2 day & $\begin{array}{l}-0.00195^{\ddagger} \\
(0.0012)\end{array}$ & $\begin{array}{l}-0.00205^{*} \\
(0.0011)\end{array}$ & $\begin{array}{l}-0.00294^{*} \\
(0.0016)\end{array}$ & $\begin{array}{l}-0.00215^{* * *} \\
(0.0008)\end{array}$ & $\begin{array}{l}-0.00245^{* *} \\
(0.0010)\end{array}$ & $\begin{array}{l}-0.00113^{\ddagger} \\
(0.0007)\end{array}$ \\
\hline 2 day (prior) & $\begin{array}{l}0.00108 \\
(0.0015)\end{array}$ & $\begin{array}{l}-0.00111 \\
(0.0016)\end{array}$ & $\begin{array}{l}0.0114^{* * * *} \\
(0.0013)\end{array}$ & $\begin{array}{l}0.00249^{* * *} \\
(0.0009)\end{array}$ & $\begin{array}{l}-0.0003 \\
(0.0009)\end{array}$ & $\begin{array}{l}0.0112^{* * *} \\
(0.0009)\end{array}$ \\
\hline 3 day & $\begin{array}{l}0.000466 \\
(0.0014)\end{array}$ & $\begin{array}{l}-0.00111 \\
(0.0014)\end{array}$ & $\begin{array}{l}0.00763^{* * * *} \\
(0.0015)\end{array}$ & $\begin{array}{l}0.000641 \\
(0.0011)\end{array}$ & $\begin{array}{l}-0.0015 \\
(0.0013)\end{array}$ & $\begin{array}{l}0.00772^{* * * *} \\
(0.0012)\end{array}$ \\
\hline Observations & 737 & 737 & 737 & 1382 & 1382 & 1382 \\
\hline \multicolumn{7}{|c|}{ Panel C: Equity events } \\
\hline 2 day & $\begin{array}{l}-0.00565^{\text {**** }} \\
(0.0017)\end{array}$ & $\begin{array}{l}-0.00576^{* * *} \\
(0.0012)\end{array}$ & $\begin{array}{l}-0.00714^{* * * *} \\
(0.0017)\end{array}$ & $\begin{array}{l}-0.00511^{* * *} \\
(0.0012)\end{array}$ & $\begin{array}{l}-0.00503^{* * *} \\
(0.0011)\end{array}$ & $\begin{array}{l}-0.00496^{\text {**** }} \\
(0.0014)\end{array}$ \\
\hline 2 day (prior) & $\begin{array}{l}0.000133 \\
(0.0019)\end{array}$ & $\begin{array}{l}-0.00152 \\
(0.0016)\end{array}$ & $\begin{array}{l}0.00853^{* * *} \\
(0.0018)\end{array}$ & $\begin{array}{l}0.0011 \\
(0.0012)\end{array}$ & $\begin{array}{l}-0.00143 \\
(0.0011)\end{array}$ & $\begin{array}{l}0.00939^{* * *} \\
(0.0016)\end{array}$ \\
\hline 3 day & $\begin{array}{l}-0.00415^{* *} \\
(0.0018)\end{array}$ & $\begin{array}{l}-0.00516^{* * *} \\
(0.0020)\end{array}$ & $\begin{array}{l}-0.000944 \\
(0.0024)\end{array}$ & $\begin{array}{l}-0.00364^{* *} \\
(0.0014)\end{array}$ & $\begin{array}{l}-0.00497^{* * *} \\
(0.0014)\end{array}$ & $\begin{array}{l}0.00096 \\
(0.0017)\end{array}$ \\
\hline Observations & 406 & 406 & 406 & 766 & 766 & 766 \\
\hline
\end{tabular}

*** $p<0.01$.

** $p<0.05$.

$p<0.1$.

$\ddagger p<0.15$. 
Robustness: additional checks.

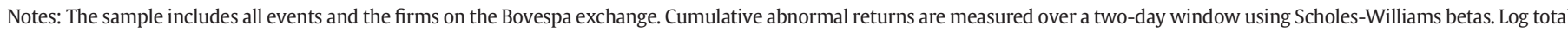

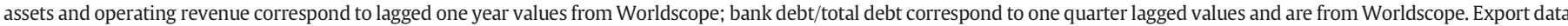

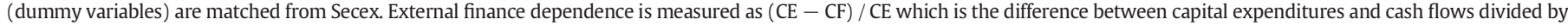

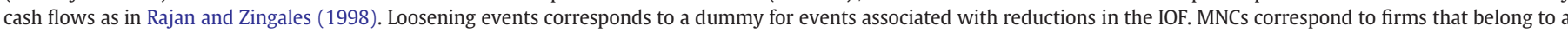

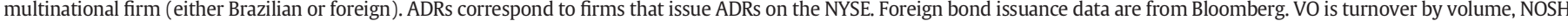
is number of shares outstanding, MCAP is market capitalization. Bootstrapped standard errors in parenthesis.

\begin{tabular}{|c|c|c|c|c|c|c|c|c|c|}
\hline & (1) & $(2)$ & (3) & (4) & (5) & (6) & (7) & (8) & (9) \\
\hline & \multicolumn{9}{|c|}{ Cumulative abnormal returns (Scholes-Williams) } \\
\hline & Bank debt & $\begin{array}{l}\text { Operating } \\
\text { revenue }\end{array}$ & MNCs & ADRs & $\begin{array}{l}\text { Foreign bond } \\
\text { issuance }\end{array}$ & VO / NOSH & $(\mathrm{VO} * \mathrm{P}) / \mathrm{MV}$ & $\begin{array}{l}(\mathrm{VO} * \mathrm{P}) / \\
\mathrm{MCAP}\end{array}$ & $\begin{array}{l}\text { Loosening } \\
\text { dummy }\end{array}$ \\
\hline Constant & $\begin{array}{l}-0.0302^{* * *} \\
(0.0113)\end{array}$ & $\begin{array}{l}-0.00466^{* * *} \\
(0.0012)\end{array}$ & $\begin{array}{l}-0.0212^{*} \\
(0.0108)\end{array}$ & $\begin{array}{l}-0.0305^{*} \\
(0.0174)\end{array}$ & $\begin{array}{l}-0.0609^{* * *} \\
(0.0156)\end{array}$ & $\begin{array}{l}-0.0267^{* * *} \\
(0.0086)\end{array}$ & $\begin{array}{l}-0.0268^{* *} \\
(0.0113)\end{array}$ & $\begin{array}{l}-0.0267^{* * *} \\
(0.0093)\end{array}$ & $\begin{array}{l}-0.0266^{* * *} \\
(0.0101)\end{array}$ \\
\hline Log total assets & $0.00155^{* *}$ & & $0.00106^{*}$ & 0.00141 & $0.00306^{* * *}$ & $0.00134^{* * *}$ & $0.00134^{* *}$ & $0.00134^{* * *}$ & $0.00134^{* *}$ \\
\hline (lag 1y) & $(0.0006)$ & & $(0.0006)$ & $(0.0010)$ & $(0.0008)$ & $(0.0005)$ & $(0.0007)$ & $(0.0005)$ & $(0.0006)$ \\
\hline \multirow[t]{2}{*}{ Exporter } & 0.00324 & $0.00346^{\ddagger}$ & $0.00372^{\ddagger}$ & $0.00610^{* *}$ & $0.00584^{\ddagger}$ & $0.00369^{*}$ & $0.00371^{*}$ & $0.00370^{*}$ & $0.00365^{*}$ \\
\hline & $(0.0026)$ & $(0.0023)$ & $(0.0025)$ & $(0.0029)$ & $(0.0039)$ & $(0.0026)$ & $(0.0022)$ & $(0.0022)$ & $(0.0024)$ \\
\hline $\begin{array}{l}\text { ExtFinDep } \\
\text { (lag 1y) }\end{array}$ & $\begin{array}{l}-0.0022^{* * *} \\
(0.0000)\end{array}$ & $\begin{array}{l}-0.00006^{* * *} \\
(0.0000)\end{array}$ & $\begin{array}{l}-0.00006^{* * *} \\
(0.0000)\end{array}$ & $\begin{array}{l}-0.0337^{\ddagger} \\
(0.0002)\end{array}$ & $\begin{array}{l}-0.00842 \\
(0.0002)\end{array}$ & $\begin{array}{l}-0.00006^{* * *} \\
(0.0000)\end{array}$ & $\begin{array}{l}-0.00006^{* * *} \\
(0.0000)\end{array}$ & $\begin{array}{l}-0.00006^{* * *} \\
(0.0000)\end{array}$ & $\begin{array}{l}-0.00006^{* * *} \\
(0.0000)\end{array}$ \\
\hline Bank debt/total debt & $\begin{array}{l}-0.0000343 \\
(0.0000)\end{array}$ & & & & & & & & \\
\hline $\begin{array}{l}\text { Operating revenue } \\
\text { (lag } 1 y)\end{array}$ & & $\begin{array}{l}4.47 \mathrm{E}-8^{*} \\
(0.0000)\end{array}$ & & & & & & & \\
\hline $\begin{array}{l}\text { VO/NOSH } \\
\text { (lag 1y) }\end{array}$ & & & & & & $\begin{array}{l}-0.00030 \\
(0.0018)\end{array}$ & & & \\
\hline $\begin{array}{l}(\mathrm{VO} * \mathrm{P}) / \mathrm{MV} \\
(\operatorname{lag} 1 \mathrm{y})\end{array}$ & & & & & & & $\begin{array}{l}2.02 \mathrm{E}-06 \\
(0.0000)\end{array}$ & & \\
\hline$(\mathrm{VO} * \mathrm{P}) / \mathrm{MCAP}$ & & & & & & & & -0.00227 & \\
\hline (lag 1y) & & & & & & & & $(0.0036)$ & \\
\hline Loosening dummy & & & & & & & & & $\begin{array}{l}-3.21 \mathrm{E}-07 \\
(0.0030)\end{array}$ \\
\hline Observations & 824 & 1011 & 714 & 452 & 309 & 989 & 989 & 989 & 999 \\
\hline R-squared & 0.008 & 0.005 & 0.005 & 0.021 & 0.035 & 0.008 & 0.008 & 0.008 & 0.008 \\
\hline Bootstrapped errors & Yes & Yes & Yes & Yes & Yes & Yes & Yes & Yes & Yes \\
\hline
\end{tabular}

A potential concern that arises is that thus far we treat capital control events of different magnitudes equally. However, the magnitudes of the changes vary across events. For example, the October 2010 event increased the IOF tax by 33\% more than the March 2008 event. To see if the effects are stronger for the events in which the changes are larger, we added event dummies to our baseline pooled regression specification (not reported). The results remain robust-on average the overall effect when the event dummy is added to the constant remains negative and significant.

We also looked at a sample of firms that are subsidiaries of multinational companies either Brazilian-owned (headquarters in Brazil) or foreign owned (headquarters abroad), obtaining a similar pattern of results (Table 8, Column 3). Also, note that in November 2009, a tax of $1.5 \%$ was imposed on American Depositary Receipts (ADRs) converted into local stocks. We also examine the impact of capital control announcements for firms that issue ADRs on the NYSE since a large fraction (approximately 40\%) of Bovespa constituents are secondarily listed for trading in New York. The coefficient on the constant is -0.0305 and is significant at the $10 \%$ level (Table 8 , Column 4).

To identify a mechanism of impact, the ADR result is also related to the focus on debt and equity stakeholders in the firm via the "bonding" hypothesis of Stulz (1999) and Coffee (1999). This literature considers global exposures measured through overseas equity issuance and trading rather than the export channel. By imposing a capital controls tax on ADRs converted into local stocks, the controls may have introduced an additional distortion in the ADR market thereby interfering with the benefits of bonding to markets with strong institutions via listing and trading ADRs. We examine another subsample of firms that issued bonds abroad during the period of study in Column 5 of Table 8. The data are from Bloomberg and company reports. The patterns of negative and highly significant coefficients on the constant term and positive and significant coefficients on size and exporter status as well as negative and significant coefficients on external finance dependence are robust in these alternative specifications.

Additionally in unreported results, we estimated the regressions for debt and equity events separately as there are some events that involve controls on both debt and equity. Examining the two sets of events separately therefore provides a cleaner identification and a simple interpretation of the coefficient on the constant. The pattern of results showed that equity-related controls had a significantly more negative impact on CARs than debt-related controls. The pattern was consistent across alternative specifications and $t$-test of means suggest a statistically different impact across the debt and equity-related coefficients.

An additional concern is one of market frictions. Brazil's market, even amongst Bovespa constituents, can be quite illiquid. The validity of standard CARs can therefore be questioned due to market illiquidity along with different market rules governing trading. Asynchronous trading implies that information is differentially incorporated into shares for larger and smaller stocks, which we interpret as globally exposed versus purely local. It is plausible that large-exporting firms may be more efficient at incorporating information than small nonexporters. While imperfect, we use liquidity measures as a proxy for transaction costs and asynchronous trading.

Table 8 Columns (6) to (8) include three measures of liquidity from Datastream: (i) VO/NOSH which is turnover by volume divided by the number of shares outstanding; (ii) The share turnover ratio $(\mathrm{VO} * \mathrm{P}) /$ MV which is the turnover by volume multiplied by the stock price (as a proxy for turnover by value) divided by the market value; and 
Table 9

Robustness: tightening and loosening events.

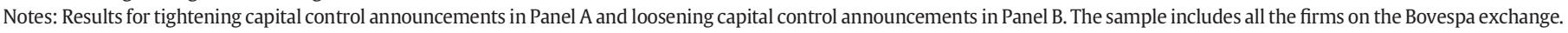

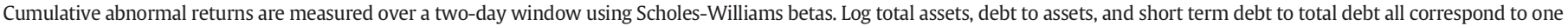
year lagged values and are from Worldscope. Export data are matched from Secex. Bootstrapped standard errors in parenthesis.

\begin{tabular}{|c|c|c|c|c|c|c|}
\hline & $(1)$ & $(2)$ & (3) & $(4)$ & (5) & (6) \\
\hline & \multicolumn{6}{|c|}{ Cumulative abnormal returns (Scholes-Williams) } \\
\hline \multicolumn{7}{|l|}{ Panel A: Tightening events } \\
\hline Constant & $\begin{array}{l}-0.00286^{* * *} \\
(0.0008)\end{array}$ & $\begin{array}{l}-0.0227^{* * *} \\
(0.0074)\end{array}$ & $\begin{array}{l}-0.0216^{* * *} \\
(0.0080)\end{array}$ & $\begin{array}{l}-0.0201^{* *} \\
(0.0088)\end{array}$ & $\begin{array}{l}-0.0236^{* * *} \\
(0.0083)\end{array}$ & $\begin{array}{l}-0.0258^{* * *} \\
(0.0085)\end{array}$ \\
\hline Log total assets & & $0.00118^{* * *}$ & $0.00114^{* *}$ & $0.000986^{*}$ & $0.00115^{* *}$ & $0.00128^{* * *}$ \\
\hline (lag 1y) & & $(0.0004)$ & $(0.0005)$ & $(0.0005)$ & $(0.0005)$ & $(0.0005)$ \\
\hline $\begin{array}{l}\text { Debt/assets } \\
(\operatorname{lag} 1 \mathrm{y})\end{array}$ & & & $\begin{array}{l}-9.98 \mathrm{E}-06 \\
(0.0001)\end{array}$ & & & \\
\hline $\begin{array}{l}\text { Short-term debt/debt } \\
\text { (lag 1y) }\end{array}$ & & & & $\begin{array}{l}0.00128 \\
(0.0037)\end{array}$ & & \\
\hline Exporter & & & & & $\begin{array}{l}0.00382^{*} \\
(0.0022)\end{array}$ & \\
\hline Export $<\$ 1$ mil & & & & & & $\begin{array}{l}-0.00238 \\
(0.0039)\end{array}$ \\
\hline Export \$1 mil-\$100 mil & & & & & & $\begin{array}{l}0.00685^{*} \\
(0.0040)\end{array}$ \\
\hline Export $>\$ 100$ mil & & & & & & $\begin{array}{l}0.00311 \\
(0.0023)\end{array}$ \\
\hline Observations & 733 & 702 & 697 & 622 & 702 & 702 \\
\hline R-squared & 0.000 & 0.006 & 0.005 & 0.004 & 0.011 & 0.016 \\
\hline \multicolumn{7}{|l|}{ Panel B: Loosening events } \\
\hline Constant & $\begin{array}{l}-0.0026 \\
(0.0023)\end{array}$ & $\begin{array}{l}-0.0361 \\
(0.0312)\end{array}$ & $\begin{array}{l}-0.0377 \\
(0.0317)\end{array}$ & $\begin{array}{l}-0.029 \\
(0.0329)\end{array}$ & $\begin{array}{l}-0.0363 \\
(0.0301)\end{array}$ & $\begin{array}{l}-0.0424^{\ddagger} \\
(0.0287)\end{array}$ \\
\hline Log total assets & & 0.002 & 0.00174 & 0.00172 & 0.00192 & 0.00228 \\
\hline (lag 1y) & & $(0.0018)$ & $(0.0018)$ & $(0.0018)$ & $(0.0018)$ & $(0.0018)$ \\
\hline Debt/assets & & & 0.000191 & & & \\
\hline (lag 1y) & & & $(0.0002)$ & & & \\
\hline $\begin{array}{l}\text { Short-term debt/debt } \\
\text { (lag 1y) }\end{array}$ & & & & $\begin{array}{l}-0.00821 \\
(0.0068)\end{array}$ & & \\
\hline Exporter & & & & & $\begin{array}{l}0.00353 \\
(0.0059)\end{array}$ & \\
\hline Export $<\$ 1 \mathrm{mil}$ & & & & & & $\begin{array}{l}-0.00458 \\
(0.0066)\end{array}$ \\
\hline Export $\$ 1$ mil- $\$ 100$ mil & & & & & & $\begin{array}{l}0.0093 \\
(0.0138)\end{array}$ \\
\hline Export $>\$ 100$ mil & & & & & & $\begin{array}{l}0.00143 \\
(0.0048)\end{array}$ \\
\hline Observations & 345 & 314 & 309 & 306 & 314 & 314 \\
\hline R-squared & 0.000 & 0.004 & 0.007 & 0.005 & 0.006 & 0.01 \\
\hline
\end{tabular}

** $p<0.01$.

** $p<0.05$.

* $p<0.1$.

$\doteqdot p<0.15$.

(iii) $(\mathrm{VO} * \mathrm{P}) / \mathrm{MC}$ which is the turnover by volume multiplied by the stock price divided by the market capitalization. Please note that for Brazilian firms, Datastream carries turnover by volume traded (VO) but not turnover by value traded (VA). We multiplied VO by the stock price $(P)$ to get a proxy for $V A$. The results remain robust to the inclusion of the liquidity measures.

In Column 9, we differentiate between tightening and loosening events using a loosening event dummy. The coefficient on the dummy is negative but not significant. The overall effect on the CARs remains negative and significant. To further investigate the impact of the removal of restrictions, Table 9 separates out the tightening and loosening events. The table shows that for tightening events the pattern of results is similar to that of the benchmark specification in Table 3. For example, Column 2 (Table 9, Panel A) which includes a proxy for firm size, the coefficient on the constant term suggests that the CARs fall on average by a quantitatively significant $-2.27 \%$ at the $1 \%$ level, an order of magnitude higher than the simple regression in Column 1 that does not control for firm size.

For loosening events in contrast, the constant is not significant in any specification. All other variables that condition for firm characteristics such as size and exporter status are also not significant. One concern of course is that the number of events and observations is substantially reduced when limiting to loosening events, which may reduce the statistical power. With this caveat in mind, we believe that the pattern may be consistent with the prior that the restrictions were removed when there is limited demand for Brazilian assets and may explain the "no response" pattern for the loosening events when considered separately. The lack of response may also be consistent with the controls were increasingly tightened before they were gradually removed such that there is an asymmetry in the market's response to tightening versus loosening controls. ${ }^{18}$

We also find that for tightening events the pattern of negative fitted CAR values for the specification in Column 2 (that controls for firm size) holds for firms in all size percentile bins barring the very largest firms in the P95 percentile (not reported). The pattern of negative fitted CARs for the specification in (Column 5 that controls for size and exporter

\footnotetext{
18 To further examine the robustness of the "no response" to loosening events, we reestimated the results using an invariant estimation window prior to the first event. Results remain robust. For brevity, result not reported but available upon request.
} 
status) holds for exporters in all size bins except for the largest exporters in the P90 and above size category. For non-exporters and tightening events, we report negative fitted CARs for all size bins including the very largest firms.

To the extent that we want to isolate the impact of the policies, it is important to control for global events or changes in global indices that can drive movements in Brazilian equities Including the S\&P500, or a global MSCI can help isolate the impact of the events on the cumulative abnormal returns. We also conducted the estimations with the MSCI world index as the benchmark market index in a world CAPM framework. Appendix Table 1 presents the results and the patterns are similar to those documented in the benchmark specification.

Given the concern of overlapping windows contaminating the estimation of expected returns, we re-estimate the benchmark specifications in Table 3 using a fixed estimation window. The results are reported in Appendix Table 2. It is interesting to note that the CARs are significantly more negative using the invariant window given that the first controls were put into place given the surge in capital inflows and against the back drop of a booming stock market. Therefore when this window is use to estimate the benchmark normal returns, the abnormal returns in the period following the controls are even more negative and statistically significant at the $1 \%$ level.

Finally, the usual assumption that the error term is random and uncorrelated across firms requires further discussion. Eq. (1) is estimated using a panel regression. When aggregating abnormal returns, typical event studies assume that abnormal returns are not correlated across firms. Assuming no correlation across firms means that the covariance between individual firm abnormal returns is zero. Therefore, standard distributional results may be used to calculate the variance of aggregated abnormal returns. The assumption is reasonable only if the event dates for individual firms do not overlap in calendar time.

In the case of a capital controls event, however, all Brazilian firms share identical event dates. Given that the capital control announcement dates are clustered in time, cross-sectional correlation of returns may result in biased standard errors and potentially incorrect inferences (Petersen, 2009). Standard event study methodology is therefore not appropriate for capital control announcements, since the announcement events are not independent across firms, and the errors from the estimation of the expected returns are correlated with one another. The covariances between individual firm abnormal returns may be non-zero, in which case the standard distributional results no longer obtain.

Moreover, there is often more than one capital control announcement to consider. To overcome this issue, Petersen (2009) proposes a methodology that takes into account the correlation in errors across firms and the possibility for several announcements. We base our test on this methodology to address the issue of residuals that may be correlated across firms or across time in panel data sets, yielding biased OLS standard errors. In particular, we use two-way clustering by relaxing the assumption that abnormal returns are not correlated across firms and time. Specifically, we allow the off-diagonal (covariance) elements in the variance-covariance matrix to be different from zero. In short, the clustering procedure produces standard errors that are appropriately adjusted to reflect the cross-firm and cross-time correlation of abnormal returns. The estimation procedure also corrects for potential heteroskedasticity across firms. In the interests of brevity, these results are not reported but a full set of estimations with clustered standard errors is available from the authors.

\section{Conclusion}

This paper examines the effects of capital controls on firm-level stock returns using data from Brazil. We focus on Brazil because it has taken center stage as a country that has implemented a series of extensive controls on capital flows between 2008 and 2013.Unlike previous capital controls episodes during emerging market financial crises designed to hinder capital flight, Brazil's capital controls were devised as a macro-prudential measure to stem foreign capital inflows in the aftermath of the Global Financial Crisis. Brazil also implemented the controls to forestall currency appreciation whereas historically emerging market countries implemented capital controls policies to prevent currency depreciation. ${ }^{19,20}$

We employ an event-study methodology using stock price and financial statement data to examine cumulative abnormal returns in the aftermath of capital controls announcements. The evidence suggests that there is a significant decline in CARs for Brazilian firms following the imposition of capital controls on equity flows, consistent with an increase in the cost of capital. The data also suggest that large firms and exporting firms are less affected by the controls. However, quantitatively the data show that the decline in average returns swamps the advantages that firm size for the firms below the 75th percentile and export status offer. Moreover, external finance dependent firms are more adversely affected by the imposition of capital controls. Notably, controls on debt flows are associated with less negative returns, suggesting that the market views controls on equity and debt flows differently.

The findings in the paper have implications for macro-finance models that focus exclusively on aggregate variables to examine the optimality of macro-prudential regulation and abstract from heterogeneity at the firm level. In particular, the evidence in this paper suggests that capital controls disproportionately affect small, non-exporting firms, especially those more dependent on external finance.

A challenge for tackling the long-standing question of the benefits and costs of open international capital markets is the tension between generalizable empirical studies based on cross-country data and the availability of precisely identifiable policy shocks. Our paper has the advantage that we can cleanly identify the implemented capital controls by type and magnitude for Brazil. We take a step in furthering our understanding of the effects of capital controls on the real economy. Future research could bring us yet nearer.

\section{Appendix A}

The IOF ("imposto sobre operacoes financeiras", how capital controls have been enacted and changed) is a "decree". Under Brazilian system, a decree ranks below a law and does not require Congress approval. The Executive can enact and change a decree, and thus the IOF taxes (up to a maximum established by the law), at any time by the Minister of Finance.

In Brazil, some taxes, which in principle have a regulatory intent (regulatory taxes) such as the IOF, gasoline tax, taxes on industrialized products, can be changed by decree. Other taxes such as the income tax (IR) have revenues as the main objective, have to be changed by law, i.e., require Congressional approval. The Tax code ("Codigo tributário") law 5172 passed in October 25th, 1966) distinguishes between taxes that can be changed by decree and those by law.

The tax code can be found at: http://www.planalto.gov.br/ccivil_03/ leis/L5172.htm.

\footnotetext{
19 Some previous noteworthy examples include the Unremunerated Reserve Requirements in Chile (1990s), Colombia (1990s, 2007), and Thailand (2006). Arguably, these historical examples do not compare to the level of active experimentation in the recent Brazilian experience.

20 In contrast to Brazil, other countries, primarily in East Asia, that also applied capital controls measures to stem the inflow of foreign capital in the aftermath of the GFC did so in somewhat of a piecemeal manner and primarily focused on the bond market and to some extent the banking sector. For instance, Taiwan implemented a tax on foreign investment in time deposits. Korea implemented restrictions on FX derivatives trading foreign-currency denominated lending by banks, and curbed the foreign currency liquidity ratio of banks, Indonesia applied one-month time limit on domestic bond investing, Thailand removed an exemption 15\% tax on foreign investors income from domestic bonds and finally Korea again applied a $14 \%$ tax on foreign income on government bonds.
} 
The links below show the subsequent reforms to the law:

(i) The IOF was created by LEI No 5.143, October 20th, 1966.

http://www.planalto.gov.br/ccivil_03/leis/L5143.htm.

(ii) Ammendment June 21st, 1994.

http://www.planalto.gov.br/ccivil_03/leis/L8894.htm.

(iii) There were some revisions to the IOF in 2011 (e.g. giving a broader definition of derivatives, tax treatments) and to include that the rates of the IOF could be changed (within the maximum limits allowed by decree) considering the fiscal and monetary goals of the authorities.

“O Poder Executivo, obedecidos os limites máximos fixados neste artigo, poderá alterar as alíquotas tendo em vista os objetivos das políticas monetária e fiscal. (Incluído pela Lei n ${ }^{\circ} 12.543$, de 2011)".

\section{Appendix B}

A sample of opinions from different constituents about capital controls is listed below. Please note that most of these articles are in Portuguese.

1. The Institute of International Finance (the IIF) criticizes measures to control capital inflows. Banks complain and criticize the capital controls policy as short sighted.

http://economia.estadao.com.br/noticias/geral-iff-critica-medidaspara-controlar-entrada-de-capital-imp-703364.

2. The industry chamber FIESP hopes that the measures will contain appreciation. They argue that the Real appreciation has "devastated" the industry. They also worry that the market will find ways to evade the measures used to contain appreciation.

http://www1.folha.uol.com.br/poder/951113-mercado-vai-burlarmedidas-para-contencao-do-cambio-diz-fiesp.shtml.

3. The head of Bovespa criticizes the tax as Brazilian firm stock prices lose US\$ 55 billion in market value after the IOF announcement.

http://www1.folha.uol.com.br/mercado/2009/10/641080-empresasbrasileiras-perdem-us-55-bi-no-pregao-apos-anuncio-do-iof.shtml.

4. Exporters repatriate dollar earnings from abroad. Interestingly, the article talks about exporters bringing back dollar earnings from exports to Brazil. Before the controls the earnings were kept abroad. This may reflect the difficulties in repatriating earnings and the fact that exporting firms could repatriate their earnings without paying the IOF tax.

http://www1.folha.uol.com.br/mercado/2009/12/671425-exportadortraz-mais-dolar-e-segura-real.shtml.

5. Article discusses that the government attitude towards containing dollar appreciation is more relevant than its results.

http://www1.folha.uol.com.br/mercado/2008/03/381611-atitudedo-governo-em-conter-dolar-e-mais-importante-que-resultados-dizfiesp.shtml.

6. Industry associations are once again in favor of the policy to regain competitiveness eroded by the Real appreciation. The article suggests that the capital control measures will not have immediate impact on the exchange rate. This article makes it clear that exporters don't pay the IOF tax.

http://www1.folha.uol.com.br/folha/dinheiro/ult91u381325.shtml.

7. Interview with Edemir Pinto, Head of Bovespa against capital controls highlighting foreign investor dependence and the importance of the stock market especially for small and medium size companies.

http://www.ft.com/cms/s/0/3734fa98-0a32-11e1-85ca-00144fe abdc0.html\#ixzz3lwzLBX8x.

8. Edemir Pinto, chief executive officer of BM\&FBovespa, met with Finance Minister Guido Mantega last month in Brasilia to lobby for a removal of the IOF tax. Pinto said Nov. 6 the tax had been "harmful" to Brazilian markets.

http://www.bloomberg.com/apps/news? pid=newsarchive\&sid= a1mzHH17Ezbo.

9. Brazilian private equity funds are lobbying the government for an exclusion to the recently increased IOF tax.

http://www.abvcap.com.br/sala-de-imprensa/noticias-abvcap. aspx?c $=$ en-US\&id $=510$.

10. Brazilian private equity funds, known as FIPs, are lobbying the government for an exclusion to the recently increased IOF tax.

http://www.latinfinance.com/Article/2698320/Brazil-Private-EquityHopes-to-Dodge-New-Tax.html\#.VZVs1_IVhBc.

11. "Brazil's largest commodities exporters are now lobbying the government to roll back the so-called IOF tax, which is applied to foreign credit and exchange operations.... "We are going to have to find some solution,"' said Luiz Carlos Carvalho, president of Brazil's Agribusiness Association, which is pressing the government to remove or alter the tax.

http://www.reuters.com/article/2012/03/30/us-exports-brazilfinanceidUSBRE82T0CV20120330.

12. International investors are outraged over Brazil's "currency war" with the US and Europe, after Brazil's latest attempt to manage its currency - by extending the IOF tax on all foreign borrowings fanned speculation it will pursue a tighter control over capital inflows in its economy..... If Brazil wants to be a real-world country, it should do real-world things and that includes not jerry-rigging your currency," says Jim Craige, international fixed-income investor in Brazil and manager of EM fixed income funds at New York's Stone Harbor Investment Partners.

http://www.euromoney.com/Article/2988821/Category/1/Channel Page/0/Investors-accuse-Brazilofjerryriggingcurrency.html?type= CategoryArticle\&ArticleId $=2988821 \&$ CategoryID $=1 \&$ PageID $=0$.

\section{Appendix C}

We present a modified outline of the model in Stulz (1981) helps fix ideas and motivate our empirical analysis. Assume there are two countries: the domestic country $D$ and the foreign country $F$. Also assume that investors in both countries are risk averse and care only about the expected return and variance of their investment. In an integrated world capital market with no barriers to international investment the two countries comprise the global equity market and expand the diversification opportunities for all investors. Since investors can invest in 
each other's stock markets, both foreign and domestic investors bear the risks associated with domestic production.

Investor $k$ is a domestic (foreign) investor if we write $k \in D(k \in F)$. An asset $i$ is a domestic (foreign) asset if we write $i \in D(i \in F)$. Also, assume that domestic investors pay a capital controls $\operatorname{tax} \theta$ on their risky international investments whereas foreign investors face no barriers to international investment. If a domestic investor $k$ holds a foreign risky asset $i$ long, the return is $R_{i}-\theta$, where $R_{i}$ is the return of asset $i$ for a foreign investor and $\theta$, the capital controls tax rate, represents barriers to international investment.

With the assumption of mean-variance optimization, investors act to minimize the variance of their portfolios subject to the constraint that the expected portfolio return is greater than an exogenously given return $R^{k}$. There are $N$ risky assets of which $n$ are domestic assets and $N-n$ are foreign assets. $R$ is the $N \times 1$ column vector of expected returns and $\Sigma$ is an $N \times N$ variance-covariance matrix of returns on risky assets. Let Let $x^{k}$ denote the $N \times 1$ vector of shares of wealth investor $k$ holds in risky assets. If $x_{i}^{k}=0$, investor $k$ does not hold a positive amount of risky asset i. If $e$ is an $N \times 1$ vector which has zeros in the first n rows (domestic) and ones in the remaining $N-n$ rows, investor $k$ pays capital controls taxes in the amount of $x^{k^{\prime}} e \theta W^{k}$ where $W^{k}$ is the investor's total wealth. Define 1 as an $N \times 1$ column vector of ones.

The investor's problem is to minimize the variance of the portfolio subject to the constraint on the expected return of the portfolio and the non-negativity constraint on $x^{k}$ and can be written as:

$$
\operatorname{Min} \frac{1}{2} x^{k^{\prime}} \Sigma x^{k}
$$

s.t.

$x^{k^{\prime}} R-x^{k^{\prime}} e \theta+\left[1-x^{k^{\prime}} 1\right] R_{f} \geq R^{k}$

$x^{k} \geq 0$

The left-hand side of Eq. (C.1) is the expected return of the portfolio of investor $k$, which is defined as the sum of:

(a) the expected return of the investor's holdings of risky assets in the absence of capital controls taxes $\left(x^{k^{\prime}} R\right)$ less

(b) the capital controls tax on the investor's holdings which is proportional to the absolute value of the investor's holdings of foreign risky assets $\left(x^{k^{\prime}} e \theta\right)$ plus

(c) the returns on holdings of safe bonds $\left(\left[1-x^{k^{\prime}} 1\right] R_{f}\right)$.

If $L^{k}$ is the Lagrangean function which corresponds to the investor's optimization problem and if $\lambda^{k}$ is the Lagrange multiplier associated with the constraint given by Eq. (C.1), then the domestic investor's portfolio has to satisfy the following first-order conditions:

$\frac{\partial L^{k}}{\partial x_{I}^{k}}=\Sigma \cdot x^{k}-\lambda^{k}\left\{R-R_{f} \cdot 1-\theta e\right\} \geq 0$

$x^{k^{\prime}} \frac{\partial L^{k}}{\partial x_{I}^{k}}=0$

Note that for the first order conditions of the foreign investor, we set $\theta=0$ in Eqs. (C.3) and (C.4).

If we use $\Sigma_{i}$ for the $i$-th row of $\Sigma$, Eq. (C.3) can be written as:

$\Sigma_{i} x^{k} \geq \lambda^{k}\left\{R_{i}-R_{f}-\theta\right\}$

where $\Sigma_{i} x^{k}$ is the covariance between the return on asset $i, R_{i}$ and the return on the investor's portfolio of risky assets $R$ Eq. (C.5) has to be satisfied for all $R_{i} \geq 0$, for all risky foreign assets in the portfolio of the domestic investor, $k$. For $\theta=0$, Eq. (C.5) must be satisfied for all domestic assets $i$ for all investors, domestic and foreign. If $\theta=0$, Eq. (C.5) reduces to:

$\Sigma_{i} x^{k} \geq \lambda^{k}\left\{R_{i}-R_{f}\right\}$

Eq. (C.6) shows that the excess return on domestic assets which are not subject to the $\operatorname{tax} \theta$ on foreign risky assets is proportional to the covariance of the return on asset $i$ with respect to the portfolio of risky assets. Eqs. (C.5) and (C.6) also represent the intuition that the share of wealth invested in asset $i$ is proportional to its Sharpe ratio. Note that in Eq. (C.5) the excess return on foreign assets is subject to the capital controls tax $\theta$.

Eq. (C.5) completely characterizes asset demands in the model. Further, from Eq. (C.5) we can show that domestic investors hold risky assets in identical proportions and this implies that a foreign asset that is not held (non-traded) by one domestic investor is non-traded for all domestic investors. The theoretical result that if the tax rate $\theta$ is positive, non-traded assets can exist implies that the world market portfolio is not an efficient portfolio for all investors. In other words, in the presence of capital controls taxes, the world market portfolio does not belong in the set of linear combinations of portfolios that yields an efficient portfolio for domestic investors.

We can now present a version of the Sharpe-Litner pricing relationship modified to account for the capital controls tax $\theta .{ }^{21}$ Since domestic stocks can be held by both domestic and foreign investors and $\theta=0$ for domestic stocks, for domestic risky assets we can write:

$\beta_{i}^{m}\left[R_{m}-R_{f}-\theta_{m}+q_{m}\right]=R_{i}-R_{f}$ for $i \in D$

where $\beta_{i}^{m}$ is the covariance of the a stock $i$ with the world market portfolio. Note that the world market portfolio includes all risky assets traded in the two countries irrespective of whether domestic investors hold all or a subset of them in their individual portfolios. $R_{m}$ is the return on the world market portfolio. $R_{f}$ is the rate on the risk-free asset. $\theta_{m}$ is the weighted average of the value of taxes that domestic investors would have to pay on one dollar invested in the world market portfolio. $q_{m}$ is a constant chosen to ensure that Eq. (C.5) holds with equality (i.e. the constraint is binding $)^{22}$ multiplied by the world market portfolio weights, $x^{m} \cdot{ }^{23}$ Note that foreign investors do not face the capital controls tax on their investments in domestic or foreign assets.

The asset pricing relationship for foreign risky assets can be written as:

$\beta_{i}^{m}\left[R_{m}-R_{f}-\theta_{m}+q_{m}\right]-\gamma^{d} \theta+\gamma^{d} q_{i}^{d}=R_{i}-R_{f}$ for $(i \in F)$

For risky foreign assets held by domestic investors, i.e. they are not in the subset of non-traded foreign stocks, $q_{i}^{d}=0$. Eq. (C.8) shows that the expected returns on two foreign stocks held in domestic investor portfolios will differ in the cross-section to the extent that they have different betas with the world market portfolio. $\gamma^{d} \theta$ is the weighted average of taxes paid by investors on their portfolio of risky assets. Since some risky assets are non-traded, the individual portfolios can differ from the world market portfolio. When there are no capital controls taxes Eqs. (C.7) and (C.8) reduce to the usual Sharpe-Litner pricing relationship.

Comparing Eqs. (C.7) and (C.8) also shows that all risky foreign assets held in domestic investor portfolios will plot on a security market line which lies above the security market line for domestic investors shifted up by $\gamma^{d} \theta$ since $q_{i}^{d}=0$ for all foreign stocks actually held. Also,

\footnotetext{
21 See Stulz (1981) for a detailed derivation.

22 Specifically, $q_{m}$ is a constant, which is a weighted average of unobservable nonnegative numbers, $q^{k}$ s chosen such that (5) holds with equality.

${ }^{23} x^{m}$ is an $N \times 1$ vector whose element $x_{i}^{m}$ is the fraction of world wealth $W^{w}$ supplied in the form of risky asset $i$.
} 
note from Eqs. (C.7) and (C.8) that a foreign stock with the same world market beta as a domestic stock will have a higher expected return. Alternatively, if a country switches regimes from having no capital con- trols taxes to one where capital controls taxes are imposed, expected returns on foreign risky assets subject to the tax will go up (e.g. a move from 1 to 2 in Fig. C.1).

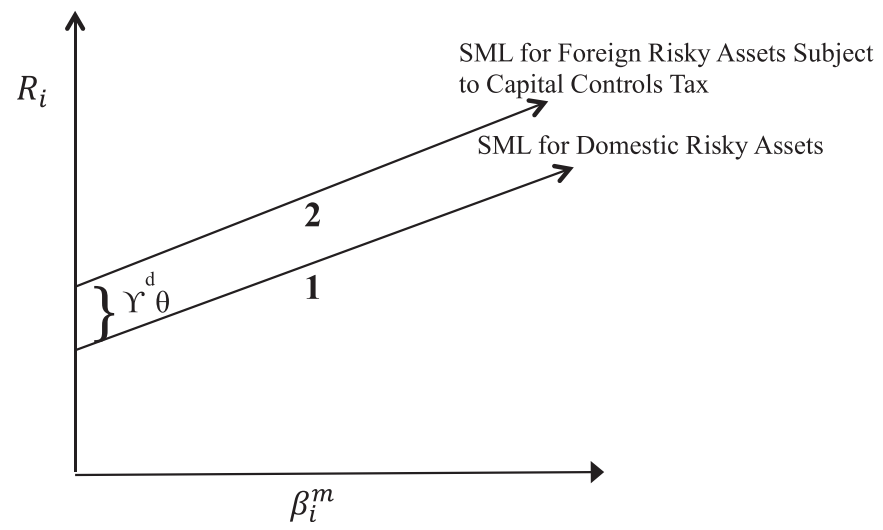

Fig. C.1

Appendix Table 1

Robustness: CARs using MSCI world index

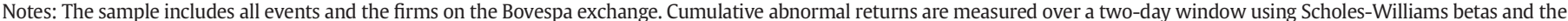

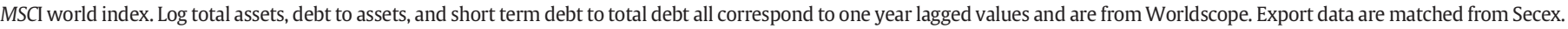
Bootstrapped standard errors in parenthesis.

\begin{tabular}{|c|c|c|c|c|c|c|}
\hline & (1) & $(2)$ & (3) & (4) & (5) & (6) \\
\hline & \multicolumn{6}{|c|}{ Panel A: Cumulative abnormal returns (Scholes-Williams) } \\
\hline & \multicolumn{6}{|c|}{ All events } \\
\hline Constant & $\begin{array}{l}-0.0329^{* * *} \\
(0.0028)\end{array}$ & $\begin{array}{l}-0.0889^{* * *} \\
(0.0231)\end{array}$ & $\begin{array}{l}-0.0759^{* * *} \\
(0.0216)\end{array}$ & $\begin{array}{l}-0.0779^{* * * *} \\
(0.0239)\end{array}$ & $\begin{array}{l}-0.0918^{* * * *} \\
(0.0221)\end{array}$ & $\begin{array}{l}-0.0935^{* * *} \\
(0.0239)\end{array}$ \\
\hline Log total assets & & $0.00336^{* *}$ & $0.00343^{* * * *}$ & $0.00332^{* *}$ & $0.00317^{* *}$ & $0.00328^{* *}$ \\
\hline (lag 1y) & & $(0.0013)$ & $(0.0012)$ & $(0.0014)$ & $(0.0012)$ & $(0.0013)$ \\
\hline $\begin{array}{l}\text { Debt/assets } \\
(\operatorname{lag} 1 \mathrm{y})\end{array}$ & & & $\begin{array}{l}-0.000452^{* * *} \\
(0.0002)\end{array}$ & & & \\
\hline $\begin{array}{l}\text { Short-term debt/debt } \\
\text { (lag 1y) }\end{array}$ & & & & $\begin{array}{l}-0.0312^{\text {*** }} \\
(0.0113)\end{array}$ & & \\
\hline Exporter & & & & & $\begin{array}{l}0.0144^{* * *} \\
(0.0049)\end{array}$ & \\
\hline Export $<\$ 1 \mathrm{mil}$ & & & & & & $\begin{array}{l}0.0264^{* *} \\
(0.0126)\end{array}$ \\
\hline Export $\$ 1 \mathrm{mil}-\$ 100 \mathrm{mil}$ & & & & & & $\begin{array}{l}0.0126^{*} \\
(0.0070)\end{array}$ \\
\hline Export $>\$ 100$ mil & & & & & & $\begin{array}{l}0.0130^{* *} \\
(0.0060)\end{array}$ \\
\hline Observations & 1078 & 1016 & $1006^{\ddagger}$ & 928 & 1016 & 1016 \\
\hline R-squared & 0.000 & 0.004 & 0.01 & 0.011 & 0.01 & 0.011 \\
\hline
\end{tabular}

*** $p<0.01$

** $p<0.05$.

* $p<0.1$.

$\ddagger p<0.15$. 


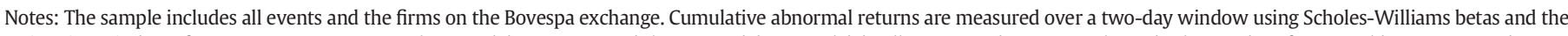

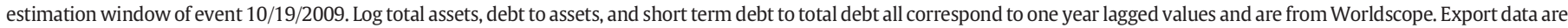
matched from Secex. Bootstrapped standard errors in parenthesis.

\begin{tabular}{|c|c|c|c|c|c|c|}
\hline & (1) & $(2)$ & (3) & (4) & (5) & (6) \\
\hline & \multicolumn{6}{|c|}{ Panel A: Cumulative abnormal returns (Scholes-Williams) } \\
\hline & \multicolumn{6}{|c|}{ All events } \\
\hline Constant & $\begin{array}{l}-0.00322^{* * *} \\
(0.0012)\end{array}$ & $\begin{array}{l}-0.0325^{* * *} \\
(0.0099)\end{array}$ & $\begin{array}{l}-0.0319^{* * *} \\
(0.0109)\end{array}$ & $\begin{array}{l}-0.0257^{* *} \\
(0.0109)\end{array}$ & $\begin{array}{l}-0.0334^{* * * *} \\
(0.0091)\end{array}$ & $\begin{array}{l}-0.0373^{* * *} \\
(0.0101)\end{array}$ \\
\hline $\begin{array}{l}\text { Log total assets } \\
(\operatorname{lag} 1 \mathrm{y})\end{array}$ & & $\begin{array}{l}0.00175^{* * *} \\
(0.0006)\end{array}$ & $\begin{array}{l}0.00164^{* * * *} \\
(0.0006)\end{array}$ & $\begin{array}{l}0.00141^{* *} \\
(0.0006)\end{array}$ & $\begin{array}{l}0.00170^{* * *} \\
(0.0005)\end{array}$ & $\begin{array}{l}0.00194^{* * *} \\
(0.0006)\end{array}$ \\
\hline $\begin{array}{l}\text { Debt/assets } \\
(\operatorname{lag} 1 \mathrm{y})\end{array}$ & & & $\begin{array}{l}0.000045 \\
(0.0001)\end{array}$ & & & \\
\hline $\begin{array}{l}\text { Short-term debt/debt } \\
(\operatorname{lag} 1 \mathrm{y})\end{array}$ & & & & $\begin{array}{l}-0.00372 \\
(0.0040)\end{array}$ & & \\
\hline Exporter & & & & & $\begin{array}{l}0.00417^{*} \\
(0.0025)\end{array}$ & \\
\hline Export $<\$ 1$ mil & & & & & & $\begin{array}{l}-0.00085^{\ddagger 9} \\
(0.0055)\end{array}$ \\
\hline Export $\$ 1 \mathrm{mil}-\$ 100 \mathrm{mil}$ & & & & & & $\begin{array}{l}0.00771^{*} \\
(0.0047)\end{array}$ \\
\hline Export $>\$ 100$ mil & & & & & & $\begin{array}{l}0.00277 \\
(0.0023)\end{array}$ \\
\hline Observations & 1037 & 980 & 972 & 896 & 980 & 980 \\
\hline R-squared & 0.000 & 0.007 & 0.007 & 0.005 & 0.011 & 0.014 \\
\hline
\end{tabular}

**** $p<0.01$

** $p<0.05$.

$* p<0.1$.

$¥ p<0.15$

\section{References}

Andrade, Gregor, Mitchell, Mark, Stafford, Erik, 2001. New Evidence and Perspectives on Mergers. J. Econ. Perspect. 15 (2), 103-120.

Auerbach, J. Alan, Hassett, Kevin A., 2007. The 2003 dividend tax cuts and the value of the firm: an event study. In: Auerbach, A., Hines, J., Slemrod, J. (Eds.), Taxing Corporate Income in the 21st Century.

Bianchi, Javier, Mendoza, Enrique, 2013. Optimal time-consistent macroprudential policy. NBER Working Papers 19704.

Black, Fischer, 1974. International capital market equilibrium with investment barriers. J. Financ. Econ. 1 (4), 337-352.

Busse, Jeffrey A., Green, T. Clifton, 2002. Market efficiency in real time. J. Financ. Econ. 65 (3), 415-437.

Chamon, Marcos, Garcia, Marcio, 2016. Capital controls in Brazil: effective? J. Int. Money Financ. 61, 163-187.

Chaney, Thomas, 2013. Liquidity constrained exporters. NBER Working Paper No. 19170.

Chari, Anusha, Henry, Peter Blair, 2004. Risk sharing and asset prices: evidence from a natural experiment. J. Financ. 59 (3), 1295-1324 (06).

Chari, Anusha, Henry, Peter Blair, 2008. Firm-specific information and the efficiency of investment. J. Financ. Econ. 87 (3), 636-655.

Coffee, John, 1999. The future as history: the prospects for global convergence in corporate governance and its implications. Northwest. Univ. Law Rev. 93 (3), 641-707.

Cutler, David M., 1988. Tax reform and the stock market: an asset price approach. Am. Econ. Rev. 78 (5), 1107-1117.

Easton, Peter D., 2004. PE ratios, PEG ratios, and estimating the implied expected rate of return on equity capital. Account. Rev. 79 (1), 73-95.

Farhi, Emmanuel, Werning, Ivan, 2014. Dilemma not trilemma? Capital controls and exchange rates with volatile capital flows. IMF Econ. Rev. (forthcoming).

Fernández, Andrés, Rebucci, Alessandro, Uribe, Martín, 2013. Are capital controls prudential? An empirical investigation. J. Monet. Econ. 76 (2015), 1-14.

Forbes, Kristin J., 2007a. One cost of the Chilean capital controls: increased financial constraints for smaller traded firms. J. Int. Econ. 71 (2), 294-323.

Forbes, Kristin J., 2007b. The microeconomic evidence on capital controls: no free lunch. In: Edwards, S. (Ed.), Capital Controls and Capital Flows in Emerging Economies: Policies, Practices, and Consequences. University of Chicago Press, Chicago.

Forbes, Kristin, Fratzscher, Marcel, Kostka, Thomas, Straub, Roland, 2016. Bubble thy neighbor: portfolio effects and externalities from capital controls. J. Int. Econ. (forthcoming).

Fratzscher, Marcel, 2012. Capital flows, push versus pull factors and the global financial crisis. J. Int. Econ. 88 (2), 341-356.

Glick, Reuven, Guo, Xueyan, Hutchison, Michael, 2006. Currency crises, capital-account liberalization, and selection bias. Rev. Econ. Stat. 88 (4), 698-714.

Goldfajn, Ilan, Minella, André, 2007. Capital flows and controls in Brazil: what have we learned? In: Edwards, S. (Ed.), Capital Controls and Capital Flows in Emerging Economies: Policies, Practices, and Consequences. University of Chicago Press, Chicago

Hail, Luzi, Leuz, Christian, 2009. Cost of capital effects and changes in growth expectations around U.S. cross-listings. J. Financ. Econ. 93 (3), 428-454.

Henry, Peter Blair, 2007. Capital account liberalization: theory, evidence and speculation. J. Econ. Lit. 45 (4), 887-935.

International Monetary Fund (IMF), 2012. The Liberalization and Management of Capital Flows. Policy Paper Washington D.C.

Jeanne, Olivier, Subrahmanian, Arvind, Williamson, John, 2012. Who Needs to Open the Capital Account? Peterson Institute for International Economics, Washington D.C.

Klein, Michael, 2012. Capital controls: gates versus walls. Brookings Papers on Economic Activity, Fall, pp. 317-355.

Korinek, Anton, 2010. Regulating capital flows to emerging markets: an externality view. Working Paper.

Lessard, Donald, 1983. Principles of international portfolio selection. In: Giddy, I.H., George, A.M. (Eds.), International Finance Handbook. Wiley, New York.

MacKinlay, A. Craig, 1997. Event studies in economics and finance. J. Econ. Lit. XXXV, 13-39.

Magud, Nicolas, Reinhart, Carmen M., 2007. Capital controls: an evaluation. Capital Controls and Capital Flows in Emerging Economies: Policies, Practices and Consequences. National Bureau of Economic Research, pp. 645-674.

Magud, Nicolas, Reinhart, Carmen, Rogoff, Kenneth, 2011. Capital controls: myth and reality-a portfolio balance approach. NBER Working Paper No. 16805.

Obstfeld, Maurice, Shambaugh, Jay C., Taylor, Alan M., 2005. The trilemma in history: tradeoffs among exchange rates, monetary policies, and capital mobility. Rev. Econ. Stat. 87 (3), 423-438.

Pasricha, Gurnain, 2017. Policy Rules for Capital Controls. Mimeo. Bank of International Settlements/Bank of Canada.

Petersen, Mitchell A., 2009. Estimating standard errors in finance panel data sets: comparing approaches. Rev. Financ. Stud. 22 (1), 435-480.

Rajan, Raghuram G., Zingales, Luigi, 1998. Financial dependence and growth. Am. Econ. Rev. 88 (3), 559-586.

Scholes, Myron, Williams, Joseph, 1977. Estimating betas from nonsynchronous data. J. Financ. Econ. 5 (3), 309-327.

Solnik, Bruno H., 1974. Why not diversify internationally rather than domestically? Financ. Anal. J. 51 (1), 89-94.

Stulz, Rene M., 1981. On the effects of barriers to international investment. J. Financ. 36 (4), 923-934

Stulz, Rene M., 1999. Globalization of Equity Markets and the Cost of Capital. Working paper. Dice Center, Ohio State University.

Stulz, Rene M., 2005. The limits of financial globalization. J. Financ. 60 (4), 1595-1638. 